American University Washington College of Law Digital Commons @ American University Washington College of Law

Articles in Law Reviews \& Other Academic Journals

Scholarship \& Research

2012

Rethinking the New Public Health

Lindsay Wiley

Follow this and additional works at: https://digitalcommons.wcl.american.edu/facsch_lawrev

Part of the Health Law and Policy Commons, Law and Society Commons, and the Torts Commons 


\title{
Rethinking the New Public Health
}

\author{
Lindsay F. Wiley ${ }^{*}$
}

\begin{abstract}
This Article contributes to an emerging theoretical debate over the legitimate scope of public health law by linking it to a particular doctrinal debate in public nuisance law. State and local governments have been largely stymied in their efforts to use public nuisance litigation against harmful industries to vindicate collectively-held, common law rights to non-interference with public health and safety. The ways in which this litigation has failed are instructive for a broader movement in public health that is only just beginning to take shape. In response to evolving scientific understanding about the determinants of health, public health advocates are rapidly implementing new law and policy tools to alter our environments and behaviors in ways that improve health at the population level. Critics of this "new public health" movement seek to safeguard individual liberty by disconnecting the law and politics of public health from its science. They argue that modern health threats such as heart disease and diabetes are individual concerns not sufficiently public in nature to trigger doctrines that privilege state intervention over individual rights. Public health scholars engaged in this theoretical debate have overlooked a related doctrinal debate within public nuisance law in which courts have struggled to define the scope of "public rights," including the right to non-interference with public health. In both debates, critics

* Assistant Professor of Law and Director of the Health Law and Justice Program at American University, Washington College of Law. The author thanks the participants in the New Scholars Panel of the Southeastern Association of Law Schools, the American University Washington College of Law Junior Faculty Workshop, and American University's Center for Health, Risk and Society where early versions of this paper were presented. Thanks are also due to Lawrence Gostin, Mark Hall, Elizabeth Weeks Leonard, Roger Magnusson, Thaddeus Pope, and Steve Vladeck for their insightful comments on drafts and suggestions of useful sources, and to Kristen Barry and Thaddeus Flood for their valuable research assistance.
\end{abstract}


have rightly insisted that the public must be more than the mere aggregation of private interests. But the narrower conceptions of the public that critics have put forth fail to account for the full scope of the state's authority and responsibility for public health. This Article stakes out a middle position by adopting the classically liberal view of public health law critics-that state interference with individual liberty requires robust justificationwhile also defining the public broadly so as to justify considerable state intervention under the banner of public health. Drawing on analysis of public nuisance litigation as a public health tool, I propose that epidemiological harms-which I define as those for which causation can be established at the population level, but not necessarily at the individual level-should be understood as public bads. This conception of the public provides a more robust justification for the new public health law movement that more firmly grounds it in the science of social epidemiology.

\section{Table of Contents}

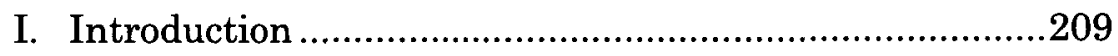

II. Public Health Law ...................................................214

A. The Evolution of Public Health Law........................215

B. The Emerging Critique of Public Health Law's Expanding Scope .........................................226

III. Public Nuisance Law ..................................................231

A. The Doctrine of Public Nuisance.............................234

B. The Evolution of Industry-Wide Public Nuisance Litigation as a Tool for Public Health ......238

C. The Scope of Public Rights in Public Nuisance Law .246

IV. Theorizing the Public in Public Health and Public Nuisance

A. Aggregation Is Insufficient....................................254

B. Public Spaces .......................................................256

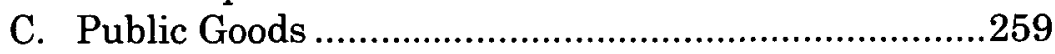

V. Epidemiological Harms as Public Bads ........................261

A. A Broader Conception of the Public .........................263 
B. The Economic Conception of Public Bads .................266

C. An Epidemiological Conception of Public Bads ........268

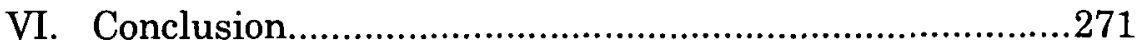

\section{Introduction}

Public health is rapidly becoming a more invasive part of our everyday lives. Walk into a Starbucks in New York City and you'll now see calorie counts listed on the menu. ${ }^{1}$ Buy a Coke in Washington, D.C. and you'll pay a sin tax on it. ${ }^{2}$ A cupcake from your local bakery might taste a little different now that trans fats have been banned from the baker's recipe. ${ }^{3} \mathrm{~A}$ session in your local tanning salon is now subject to a $10 \%$ federal excise tax. ${ }^{4}$ Soon, if you pick up a pack of cigarettes purchased in the United States, you might be brought face-to-face with a large, graphic image of a diseased lung, an autopsied corpse, or a mouth full of sores and rotten teeth. ${ }^{5}$ Public health is also becoming a more prominent

1. See generally Bryan Bollinger et al., Calorie Posting in Chain Restaurants, Stanford Graduate Sch. Bus. News (Jan. 2010), http:// www.gsb.stanford.edu/NEWS/StarbucksCaloriePostingStudy.pdf (presenting a study of data from Starbucks finding that calorie labeling on menus in compliance with New York City law decreased average calories per purchase and did not significantly harm revenues).

2. See Michael Nebauer, D.C. OKs Soda Tax, Rejects Income Tax Increase, WASH. BUS. J. (May 26, 2010), http://www.bizjournals.com/washington/stories/ 2010/05/24/daily33.html (last visited Jan. 28, 2012) (on file with the Washington and Lee Law Review).

3. See M.E. Malone, Cooking Up Ways to Lose Trans Fat: New Ban has Bakers Adjusting their Recipes, BosToN GLOBE (Feb. 25, 2009), available at http://www.boston.com/lifestyle/food/articles/2009/02/25/cooking_up_ways_to_los e_trans_fat/ (last visited Jan. 28, 2012) (on file with the Washington and Lee Law Review).

4. See Internal Revenue Service, Excise Tax on Indoor Tanning Services Frequently Asked Questions (June 6, 2011), http://www.irs.gov/businesses/small article $/ 0$, id $=224600,00 . \mathrm{html}$ (last visited Jan. 28, 2012) (on file with the Washington and Lee Law Review).

5. Catherine Pearson, New Cigarette Warnings Released, HuffingtoN Post (June 21, 2011), http://www.huffingtonpost.com/2011/06/20/cigarettewarnings-labels-photos-fda_n_880885.html (last visited Jan. 28, 2012) (on file with the Washington and Lee Law Review). In November 2011, a federal district court issued a preliminary injunction blocking implementation of the graphic warning requirement. R.J. Reynolds Tobacco Co. v. U.S. Food and Drug Administration, 11-CV-1482 (D.D.C. 2011), available at http://pubcit.typepad. 
litigation risk for businesses. Manufacturers and distributors of harmful products like asbestos, tobacco, lead paint, and firearms are facing not only private plaintiffs, but also federal, state, and city attorneys. ${ }^{6}$ In their parens patriae capacity, ${ }^{7}$ governmental plaintiffs have brought public nuisance suits against these industries to vindicate collectively held, common law rights to non-interference with public health and safety. ${ }^{8}$

It used to be that problems like heart disease, diabetes, and cancer were brought to our attention primarily through public service announcements and warnings from our doctors urging us to eat better, exercise, stop smoking, and slather on sunscreen. These messages sought to bring home the dire consequences that would result from our unhealthy choices. But the more subtle message was that these problems were a matter of our choices, a matter of private concern and personal responsibility. That message is changing. As the government is taking on a greater role in paying for costly medical treatment, the public's interest in preventing disease and injury is increasing. ${ }^{9}$ At the same time, public health research is revealing the important role played by social, economic, and environmental factors in constraining people's behavior choices and determining health outcomes. ${ }^{10}$

com/files/rjr-v-fda-op.pdf.

6. See infra Part III.B.

7. See Alexander Lemann, Sheep in Wolves' Clothing: Removing Parens Patriae Suits Under the Class Action Fairness Act, 111 CoLUM. L. REv. 121, 122 (2011)

The doctrine of parens patriae gives a state standing to sue on behalf of its citizens. Although it derives from the "royal prerogative" granted to the King of England to sue on behalf of "helpless" subjects like children and the mentally incompetent, parens patriae has been expanded in the twentieth century by a series of Supreme Court decisions, and has been an increasingly popular vehicle for state attorneys general to vindicate the rights of their constituents.

8. See infra Part III.A.

9. This connection is readily apparent in the provisions of the Patient Protection and Affordable Care Act that address public health. See Thaddeus Mason Pope, The Slow Transition of U.S. Law Toward a Greater Emphasis on Prevention, in Prevention vs. Treatment: Philosophical, EMpirical and Cultural Reflections (Halley S. Faust \& Paul T. Menzel eds., forthcoming 2011) (manuscript at 13-15), available at http://papers.ssrn.com/sol3/papers. cfm?abstract_id $=1734405$ (describing the main provisions of the PPACA relevant to public health) (on file with the Washington and Lee Law Review).

10. See infra Part II.A. 
Influenced by the "new public health" movement, ${ }^{11}$ public health law scholars have begun to redefine their relevance to the science and practice of public health-as well as to the broader law and policy community - by seeking to use law as a tool to protect and promote the public's health. ${ }^{12}$ The result is an emerging debate over the legitimate scope of the government's role in ensuring access not just to health care, but to healthy lifestyles and living conditions as well. Increasingly, health threats such as diabetes and heart disease are not simply viewed as personal failures to be addressed through clinical prevention and treatment. In the new era, they are seen as public problems amenable to structural solutions.

The law and policy strategies of new public health are generating controversy on multiple levels. In the blogosphere, media pundits are serving up scathing condemnations of what they view as overreaching public health interventions. ${ }^{13}$ In the

11. The "new public health" label has been used by public health scientists, ethicists, and legal scholars. See, e.g., THEOdoRE H. TUlChinsKY \& Elena A. Varavikova, The New Public Health (2d ed. 2009); Awofeso, infra note 26; New Ethics for the Public's Health (Dan E. Beauchamp \& Bonnie Steinbock, eds., 1999); Wendy E. Parmet \& Richard Daynard, The New Public Health Litigation, 21 ANN. REV. OF PuB. HEALTH 437 (2000); Richard A. Epstein, Let the Shoemaker Stick to His Last: In Defense of the "Old" Public Health, 46 PERSP. BIOLOGY \& MED. S138 (2003) (critiquing "new public health").

12. See Lawrence O. Gostin, Public Health Law: Power, Duty, RESTRAINT 29 (2d ed. 2008) (offering "a taxonomy of legal tools available to government and private citizens to advance the public's health: taxation and spending, alteration of the informational environment, alteration of the built environment, alteration of the socioeconomic environment, direct regulation, indirect regulation through the tort system, and deregulation"); Scott Burris, From Health Care Law to the Social Determinants of Health: A Public Health Law Research Perspective, 159 U. PA. L. REv. 1649, 1651-52 (2011) (describing the role of public health law research in "identifying and ameliorating social causes of the country's relatively poor level and distribution of health").

13. See generally William Saletan, Then They Came for the Fresca: The Growing Ambitions of the Food Police, SLATE (Sept. 22, 2009), http://www.slate. com/id/2229194/ (last visited Jan. 28, 2012) (on file with the Washington and Lee Law Review); Greg Beato, The Vanity Tax: The Trouble with the Government's New Tax on Indoor Tanning Services, REASON FOUND (June 17, 2010), http://reason.org/news/show/vanity-tax-tanning (last visited Jan. 28, 2012) (on file with the Washington and Lee Law Review); Mario Rizzo, The Attack on Dignity and Moral Autonomy: The Case of Cigarettes, THINKMARKETS (June 26, 2011), http://thinkmarkets.wordpress.com/2011/06/26/the-attack-ondignity-and-moral-autonomy-the-case-of-cigarettes/ (last visited Jan. 28, 2012) (on file with the Washington and Lee Law Review). 
academic literature, a handful of scholars have put forward a critique of the rapidly expanding scope of public health as a field of science, practice, and law. ${ }^{14}$ And in the courts, litigants are arguing about which health and safety concerns are legitimately viewed as public in nature, such that doctrines privileging the role of the state should be brought into play. ${ }^{15}$

This Article contributes to an emerging theoretical debate over the legitimate scope of public health law by linking it to a particular doctrinal debate that has arisen in the context of public nuisance litigation brought by state and local governments against industries that allegedly interfere with the public's health. Both debates focus on the meaning of the "public" as a justification for government intervention. In public health law, the theoretical dispute is over what makes any particular health threat sufficiently public in nature to come within the realm of public health. Critics of the new public health movement have argued that the politics and law of public health should be disconnected from the science of new public health as a means of safeguarding individual liberty. ${ }^{16}$ In public nuisance law, the doctrinal dispute is over the meaning of "public rights" (including collectively held, common law rights to public health and public safety), interference with which is a key element of the public nuisance cause of action. In both disputes, the stakes are high. If a concern is designated as a public health threat, legal doctrines that privilege state intervention over private interests come into play. If a state or city government bringing suit in parens patriae successfully establishes interference with a public right, the door is opened to flexible doctrines of causation and fault that make liability more likely. In both debates, critics of a broad definition of the public insist that it must be more than the mere aggregation of private interests. In theorizing a narrower conception of the public, some have attempted to define this "something more" in terms of public and private physical spaces.

14. See infra Part II.B.

15. See infra Part III.C.

16. A public nuisance is generally defined as a substantial and unreasonable interference with a right held in common by the general public. See infra Part III.A. But there is considerable disagreement over what kinds of interests properly fall within the realm of public rights. See infra Part III.C. 
Others have defined it in economic terms by linking public health and public rights to the securing of public goods.

This Article stakes out a middle position that adopts the classically liberal view of public health law critics-that state interference with individual liberty requires robust justificationwhile also defining the public broadly so as to justify considerable state intervention under the banner of public health. I agree with the initial premise of the critics that the public must be defined in terms of something more than the mere aggregation of private interests. But as a defender for the new public health movement, I argue that neither of the narrower conceptions offered by critics-the public physical spaces approach, nor the public goods approach-adequately accounts for the appropriate scope of the state's authority and responsibility for public health. Drawing on my analysis of public nuisance litigation as a public health tool, I propose an alternative approach to theorizing the particularly public nature of public health threats. I suggest that the concept of public bads has been underutilized in justifying state intervention to promote public health. I also argue that the economic understanding of public bads-as negative externalities inflicted on the public without consent-might be supplemented by an epidemiological understanding. Epidemiological harmswhich I define as those for which causation can be established at the population level, but not necessarily at the individual levelshould be understood as public bads. This concept has the potential to provide a more robust understanding of the public that may be invoked in justification of public health interventions. Rather than advocating for a division between the science and politics of public health as a means of protecting individual liberty, my proposal seeks to root the new public health law movement even more firmly in the science of social epidemiology as a means of incorporating the communitarian vision of public health within a legal tradition that is still fundamentally liberal.

In Part II, I describe the evolution of public health law in response to changing models of public health science and practice. I also describe the emerging liberal critique of the now dominant ecological model of public health-which emphasizes the role of social and environmental interventions to promote health-and the resulting theoretical debate over the new public health law 
movement. In Part III, I shift my attention to the use of public nuisance litigation as a tool of the new public health law movement. I provide a brief discussion of the historical development and doctrine of public nuisance law with emphasis on its recent use against the asbestos, tobacco, lead paint, and firearm industries. I then introduce the doctrinal debate over the proper scope of the collectively held common law rights that are vindicated through public nuisance suits. In Part IV, I link these two debates, analyzing the narrow notion of the public put forward by critics in both contexts. In Part V, I propose that protection of the public from public bads-understood in epidemiological, rather than merely economic, terms-should supplement securing of "public goods" as a justification for public health interventions and public nuisance liability.

\section{Public Health Law}

Public health focuses on health at a population, rather than individual, level. Its core science is epidemiology, ${ }^{17}$ and its core mission is explicitly progressive. Rather than being concerned with the treatment of medical conditions on a case-by-case basis, public health examines trends in health, illness, and injury in an effort to understand their causes and develop interventions to address them. ${ }^{18}$ In broad terms, public health has been described as "what we, as a society, do collectively to assure the conditions

17. Even the definition of epidemiology as a discipline has experienced evolution. See LEON GORDIS, EPIDEMIOLOGY 3 (3d ed. 2004)

Epidemiology is the study of how disease is distributed in populations and the factors that influence or determine this distribution.... A broader definition... has been widely accepted. It defines epidemiology as "the study of the distribution and determinants of health-related states or events in specified populations and the application of this study to control of health problems." What is noteworthy about this definition is that it includes both a description of the content of the discipline and the purpose or application for which epidemiologic investigations are carried out.

18. See Geoffrey Rose, Sick Individuals and Sick Populations, in PUBLIC Health Ethics: Theory, Policy, and Practice 33 (Ronald Bayer et al. eds., 2007) (distinguishing between the individual-centered etiology used in clinical medicine-which "seeks the causes of cases"-and the population-focused etiology used in public health-which "seeks the causes of incidence"). 
for people to be healthy." 19 The notion of the "common good" is fundamental to this enterprise:

The health of the public is [a] shared value. Not only does each individual have an interest in staying healthy but also all of us together share an interest in having a healthy population.... [W] e may disagree about the best ways to promote the public's health and how to weigh individual liberty against the welfare of the whole. Nevertheless, reducing disease, saving lives, and promoting good health are shared values, part of the common good. ${ }^{20}$

Despite wide acceptance of the value of public health, interventions to protect it frequently generate political controversy, particularly when they make use of state authority. ${ }^{21}$ Public health law lives in the thick of this controversy: it defines the scope of the state's authority and obligation to protect and promote the public's health.

\section{A. The Evolution of Public Health Law}

Public health law is experiencing a massive transformation. ${ }^{22}$ For much of the twentieth century, it was defined primarily as

19. Comm'n For the Study of The Future of PUb. HeAlth, InSt. Of MEd., The Future of Public Health 19 (1988) [hereinafter Future of Public HEALTH].

20. Introduction: Ethical Theory and Public Health, in PuBLIC HEALTH Ethics: Theory, Policy, AND Practice 20 (Ronald Bayer et al. eds., 2007); see also GostiN, supra note 12, at 21 ("Social justice is viewed as so central to the mission of public health that it has been described as the field's core value.").

21. See Gostin, supra note 12, at 39 ("[T] highly political, with conservative scholars urging limited state action and progressive scholars urging far-reaching politics.").

22. See, e.g., id. at xxi-xxii (noting that "scholarly attention to the field of public health law has surged"); WEndy E. PARMET, Populations, Public HEALTH, AND THE LAW 272 (2009) (describing the "reemergence of public health law"); Pope, supra note 9, at 34 (describing the "revitalization" of public health law "after a nearly fifty-year slumber"); Elizabeth Weeks Leonard, Public Health Law for a Brave New World, 9 Hous. J. Health L. \& Pol'y 181, 182 (2009) (describing the "burgeoning" of public health law); Benjamin Mason Meier, James G. Hodge, Jr. \& Kristie M. Gebbie, Transitions in State Public Health Law: Comparative Analysis of State Public Health Law Reform Following the Turning Point Model Statute, 99 AM. J. PUB. HEalTH 423, 424-29 (2009) (documenting the "modernization" of state public health law). 
the law of communicable disease control. ${ }^{23}$ Compulsory vaccination and treatment, isolation and quarantine, and surveillance of health data were its main subjects. Critics have argued that this "old" public health law of communicable disease control represents the legitimate scope of the field. ${ }^{24}$ They take issue with public health law's new focus on chronic disease as well as acute communicable disease outbreaks. They are particularly wary of the influence of social epidemiology_which has exposed the crucial role of social, economic, and environmental factors in determining health outcomes ${ }^{25}$-on the new public health law movement.

Critics have vastly oversimplified the contrast between the "old" public health law and the "new." The development of public health law has always been influenced by expanding models of public health science and practice. Scholars have identified four basic eras in the history of public health, each with an accompanying paradigm for understanding the determinants of health: the miasma model, the agent model, the behavioral model, and the ecological model. ${ }^{26}$ Each model represents a

23. See, e.g., Lawrence O. Gostin, Scott Burris \& Zita Lazzarini, The Law and the Public's Health: A Study of Infectious Disease Law in the United States, 99 CoLUM. L. REV. 59, 62 (1999) ("W]e focus on communicable disease law, both because of what it has meant to public health and because of its likely importance in the future.").

24. See infra Part II.B.

25. See generally LISA F. BERKMAN \& ICHIRo KAWACHI, SOcIAL EPIDEMiology (2000); JULIE G. CWIKEL, SOCIAL EPIDEMIology: STRATEgIES FOR Public Health ACTIVISM (2006). For a critical discussion of the emergence of social epidemiology as a distinct field, see generally Gerhard A. Zielhuis \& Lambertus A.L.M. Kiemeney, Social Epidemiology? No Way, 30 INT'L J. EPIDEMIOLOGY 43 (2001).

26. My admittedly oversimplified typology draws heavily from two sources. In an influential 1996 article in the American Journal of Public Health, Mervyn Susser and Ezra Susser described three eras in epidemiology, each with its own dominant paradigm: "(1) the era of sanitary statistics with its paradigm miasma; (2) the era of infectious disease epidemiology with its paradigm the germ theory; and (3) the era of chronic disease epidemiology with its paradigm the black box." Mervyn Susser \& Ezra Susser, Choosing a Future for Epidemiology: I. Eras and Paradigms, 86 AM. J. PUB. Health 668, 668-69 (1996). They also suggested that a new paradigm, which they did not label, was on the horizon. Id.; see also Niyi Awofeso, What's New About the "New Public Health", 94 AM. J. PUB. HEALTH 705 (2004) (presenting the history of public health eras); P. Hanlon et al., Making the Case for a 'Fifth Wave' in Public Health, 125 Public Health 30 (2011); Elizabeth Fee, The Origins and 
particular approach to combating disease and promoting health. The relevance of law and policy tools to the project of public health has varied from model to model, as has the type of controversy generated by their use.

In early nineteenth-century Western Europe and the United States, Sanitarians subscribing to the "miasma" model studied and sought to improve the physical environment in urban slums as a means of fighting disease. ${ }^{27}$ They attributed disease to "poisoning by foul emanations from the soil, water, and environing air." 28 They "studied a wide range of industries and occupations; detected many hazards from dusts, heavy metals, and general working conditions; and conducted national surveys of diet, parasite-infested meat, and food contamination." 29 They

Development of Public Health in the United States, in 1 OXford TEXTBOOK OF Public Health: The ScOPE of PUBlic Health (Roger Detels et al., ed.) (3d ed. 1997), reprinted in LaWrence O. Gostin, Public Health Law and Ethics: A READER 27 (1st ed. 2002). In their seminal article on the revival of public health law, Lawrence Gostin, Scott Burris, and Zita Lazzarini pointed to three conceptual models of public health: "microbial," "behavioral," and "ecological." Gostin et al., supra note 23, at 69-70. The typologies offered by Gostin, et al. and Susser and Susser are admittedly oversimplified, as is my own. I have followed Susser and Susser in attributing each model to a particular historical era. The "evolution" story provides a useful way of understanding the development of public health law, but it does belie considerable overlap among the three models during any given time frame. See Roger Magnusson, Mapping the Scope and Opportunities for Public Health Law in Liberal Democracies, 35 J.L. MED. \& ETHICS 571, 574 (2007) ("The 20th century reflects a gradual broadening of the determinants that are understood to contribute to states of health and illness in the population, and a growing realization of their complexity and inter-relationship. This historical shift has important implications for public health law."). I have re-labeled the "microbial" model described by Gostin, et al. as the "agent" model to reflect its applicability to noninfectious diseases. For example, applied to the problem of heart disease, the agent model might emphasize cholesterol as the agent and point toward the use of cholesterol lowering drugs. Upon a close reading fifteen years after its original publication, Susser and Susser's "black box" paradigm-which "related exposure to outcome" with less attention to pathogenesis-and their description of a new era on the horizon each appear to combine aspects of the behavioral model with an early version of the ecological model. See Susser \& Susser, supra, at 671 (describing the black box paradigm as being associated with a "web of causation" and noting that "the failure to control the disease resides in our lack of understanding of transmission and illness in the social context").

27. See generally George Rosen, A History of Public Health 1, 220-26 (expanded ed. 1993).

28. Susser \& Susser, supra note 26, at 669.

29. Id. 
championed public expenditures on "[c]losed drainage and sewage systems, supplemented by garbage collection, public baths, and housing [as] remedies that would disperse miasma, reduce mortality and morbidity (as indeed they did), and dispel the poverty of the new urban poor (as indeed they did not)." 30 They also advocated for comprehensive legislation to establish state and local health authorities and to regulate commercial activities harmful to the public's health. ${ }^{31}$ In the United States, The Slaughterhouse Cases ${ }^{32}$ arose out of this effort. The U.S. Supreme Court upheld the efforts of the City of New Orleans to bring slaughterhouse operations under control and, thus, protect citizens from cholera outbreaks. ${ }^{33}$ In doing so, the Court affirmed the preeminence of the state's police power" ${ }^{34}$ to protect "the security of the social order, the life and health of the citizen, the comfort of an existence in a thickly populated community, the enjoyment of private and social life, and the beneficial use of property." 35

Around the turn of the twentieth century, scientists conclusively determined that diseases were attributable to specific causes rather than to general environmental miasmas. ${ }^{36}$ The gradual identification of the bacteria, viruses, and toxins responsible for illness made effective vaccination and medical treatment possible. ${ }^{37}$ It also resulted in a major shift toward the "agent" model of public health. ${ }^{38}$ Unlike the Sanitarians'

30. Id.

31. See William J. NovaK, The People's Welfare: LaW and Regulation IN NINETEENTH-CENTURY AMERICA 168-269 (1996); RosEN, supra note 27, at 168269.

32. Slaughterhouse Cases, 83 U.S. 36 (1873) (consolidating three similar cases).

33. The reading of the Fourteenth Amendment put forth in the Slaughterhouse Cases has generated harsh criticism, but scholars have rehabilitated the public health rationale behind the slaughterhouse regulation in recent years. See generally RONALD M. LABBÉ \& JONATHAN LURIE, THE Slaughterhouse Cases: Regulation, Reconstruction, and the Fourteenth AMENDMENT (2003).

34. Lawrence O. Gostin, Jacobson v. Massachusetts at 100 Years: Police Power and Civil Liberties in Tension, 95 AM. J. PuB. Health 576, 577 (2005).

35. Slaughterhouse Cases, 83 U.S. at 62.

36. See TULCHINSKY \& VARAVIKOVA, supra note 11, at 14.

37. See id.

38. See Susser \& Susser, supra note 26, at 670 (describing germ theory as 
environmentally focused interventions, the interventions associated with the agent model were applied to individuals. "The appropriate responses were to limit transmission by vaccines, to isolate those affected, and, ultimately, to cure with chemotherapy and antibiotics." 39 But vaccination and treatment can only eradicate an infectious disease if a high percentage of the population is immunized, which creates community, or "herd," immunity. 40 The risks of immunization, perhaps amplified by mistrust, led some to resist. Legislators thus adopted compulsory measures to ensure adequate uptake. This period yielded Jacobson v. Massachusetts, ${ }^{41}$ in which the U.S. Supreme Court upheld compulsory vaccination for smallpox. ${ }^{42}$ Relying on the "social compact [whereby] ... the whole people covenants with each citizen and each citizen with the whole people, that all shall be governed by certain laws for "the common good," 43 the Court made clear that public health measures occupied a special place in American law. ${ }^{44}$

In the second half of the twentieth century, as chronic, noninfectious diseases overtook communicable diseases as the leading causes of death in wealthy countries, ${ }^{45}$ the public health

focusing on "single agents relating one to one to specific diseases").

39. Id.

40. See Nat'l Inst. of Allergy and Infectious Diseases, Community Immunity ("Herd Immunity") (Oct. 21, 2010), http://www.niaid.nih.gov/ topics/pages/communityimmunity.aspx (last visited Jan. 28, 2012) ("When a critical portion of a community is immunized against a contagious disease, most members of the community are protected against that disease because there is little opportunity for an outbreak. Even those who are not eligible for certain vaccines get some protection because the spread of contagious disease is contained.") (on file with the Washington and Lee Law Review). Of course, this is also the reason that herd immunity presents a potential free rider problem whereby a few who go unvaccinated by choice are able to benefit from the risks borne by those who opt for vaccination. See Gil Siegal et al., Policy, Politics, and Collective Action: An Account of Collective Actions in Public Health, 99 AM. J. PUB. HEALTH 1583, 1583 (2009).

41. Jacobson v. Massachusetts, 197 U.S. 11 (1905).

42. Id. at 49 .

43. Id. at 27 .

44. See Gostin, supra note 12, at 123 ("The Jacobson Court's use of social compact theory to support this expansive understanding of police power was unmistakable.").

45. See, e.g., J.P. Machenbach, The Epidemiological Transition Theory, 48 J. Epidemiology \& Community Health 329, 329 (1994) ("It is the transition 
model shifted once again toward the "behavioral" model.46 Initially at least, the medical etiology of these diseases was poorly understood, making the agent model inapposite. ${ }^{47}$ Eventually, problems like ischemic heart disease, certain cancers, and typetwo diabetes were associated with behaviors like poor eating and exercise habits, tobacco consumption, and excessive sun exposure. ${ }^{48}$ Later, HIV/AIDS was similarly associated with unprotected sexual intercourse and intravenous drug use.$^{49}$ Based on these observations, the behavioral model of public health advocated individual behavior change as a preventive approach. ${ }^{50}$ Informing people of the risks associated with smoking, lack of exercise, or risky sexual behavior was seen primarily as a task for physicians counseling individual patients. ${ }^{51}$ It was a project to

from a cause of death pattern dominated by infectious diseases with very high mortality, especially at younger ages, to a pattern dominated by chronic diseases and injuries with lower mortality, mostly peaking at older ages, that is seen to be responsible for the tremendous increase in life expectancy."); Susser \& Susser, supra note 26, at 670 ("Shortly after [World War II] ended, it was clear that, in the developed world, rising chronic disease mortality had overtaken mortality from infectious disease.").

46. See Susser \& Susser, supra note 26, at 670 ("With the emerging predominance of chronic disease of unknown cause, under any credible causal paradigm the social and physical environment had now to be reckoned with once more.").

47. See id. ("Epidemiologists were faced once more, as in the Sanitary Era, with major mortal diseases of completely unknown origin.").

48. See Ali H. Mokdad et al., Actual Causes of Death in the United States, 2000, 291 J. AM. MED. Ass'N 1238, 1239-42 (2004) (contrasting clinical causes of death with the "real" cause of disease, including tobacco, poor diet and physical inactivity, etc.).

49. In response to the association of HIV/AIDS with particular behaviors (some of which are criminalized), advocates have emphasized the role of civil and political rights in promoting population health. See, e.g., Jonathan M. Mann et al., Health and Human Rights, 1 HEALTH \& HuM. RTS. 6, 19-22 (1999). More recently, public health law scholars have examined the role of law itself as a social determinant of health. They have noted that the criminalization of drug use, sex work, and certain sexual behaviors has created an environment that is not conducive to an effective public health response to HIV/AIDS. See, e.g., Scott Burris et al., Racial Disparities in Injection-Related HIV: A Case Study of Toxic Law, 82 TEMP. L. REV. 1263, 1267 (2010).

50. See Susser \& Susser, supra note 26, at 670 ("Once the major infectious agents seemed all to have been identified and communicable disease no longer overwhelmed all other mortal disorders, the force of the germ theory paradigm faded.").

51. See, e.g., U.S. Preventive Serv. Task Force, Guide to Clinical 
which the law (initially at least) had little relevance. ${ }^{52}$ At a time when behavioral interventions dominated public health's approach to so-called "lifestyle" diseases, public health law became a considerably less important part of the American legal landscape. ${ }^{53}$ Its primary statutes were left unrevised and largely unused for decades. ${ }^{54}$

Stymied in their efforts to convince people to change their behaviors, advocates and researchers began to investigate the ways in which external factors constrained people's behavior choices and health outcomes. ${ }^{55}$ In the late twentieth century, their model of public health expanded yet again to encompass not only the properties of the agent of disease or injury, and not only the behaviors of the individual, but also the social, economic, and

Preventative Services: Report of the U.S. Preventative Serv. Task Force LXXV (Carolyn DiGuiseppi et al. eds., $2 d$ ed. 1996) (noting that prevention of conditions created by unhealthy behavior choices "requires active participation by the patient with guidance and support from the clinician").

52. A notable exception during this era was found in the area of injury prevention. See Susser \& Susser, supra note 26, at 649. Seatbelt and helmet use were mandated by law in a growing number of jurisdictions, despite arguments that the behavior of going without these protections was primarily selfregarding and thus restriction of liberty was not warranted. Id. at 649-50; Gostin et al., supra note 23 , at 73 . Challenges to seatbelt and helmet laws were upheld, however, on paternalistic grounds as well as on the basis of the negative externalities imposed by risk-takers on society. Id. at 64 . Bans on smoking, particularly in confined public spaces such as airplanes and restaurants, also began to take hold. Thaddeus Mason Pope, Balancing Public Health Against Individual Liberty: The Ethics of Smoking Regulations, 61 U. PITT. L. REV. 419, $441(2000)$. These were justified (via the harm principle) by the nuisance and health harms attributable to secondhand smoke. Id. at 442.

53. See Magnusson, supra note 26, at 574 (noting that "public health went into decline in the post-war period; public health practitioners became rolebound as managers of state-provided clinical services, while research money followed the biomedical model").

54. See Future of Public Health, supra note 19, at 10 (calling on states to review their public health statutes and make revisions necessary to, inter alia, "support a set of modern disease control measures that address contemporary health problems such as AIDS, cancer, and heart disease").

55. See Susser \& Susser, supra note 26, at 670 ("With the emerging predominance of chronic disease of unknown cause, under any credible causal paradigm the social and physical environment had now to be reckoned with once more."); id. at 671 ("We know which social behaviors need to change, but we know little about how to change them, even when entire societies are at stake."); Michael G. Marmot, Understanding Social Inequalities in Health, 46 PERSP. BIOLOGY \& MED. S9, S15-S16 (Supp. 2003) (comprehensively describing the social determinants of health). 
physical environment in which the agent and individual interact. ${ }^{56}$ The development of the now-dominant "ecological" model of health has been heavily influenced by social epidemiology, which demonstrates that socially, culturally, and materially disadvantaged people live shorter, less healthy lives. ${ }^{57}$ This association persists across nearly every type and degree of disadvantage that one can imagine. It seems to be firmly entrenched even in places with universal health care, suggesting that differential access to healthy living conditions and lifestyles plays a greater role in determining health disparities than differential access to medical care. ${ }^{58}$

The ecological model places supposedly private, individual choices into their social context and emphasizes structural explanations for health behaviors and outcomes. In this view, eating a diet high in calories and fat and low in nutrients is not merely a matter of personal choice. It is a behavior that is influenced by environmental factors: an information environment that is loaded with commercial marketing ${ }^{59}$ and a food

56. See TUlChINSKY \& VARAVIKova, supra note 11, at xxiv ("The New Public Health incorporates a wide range of interventions in the physical and social environment, health behavior, and biomedical methods, along with health care organization and financing."); U.S. DEP'T OF HEALTH \& HuMAN SERV., HEALTHY PEOPle 2010: Understanding AND ImPRoving HeALTH 18 (2d ed. 2000) ("Individual biology and behaviors influence health through their interaction with each other and with the individual's social and physical environments. In addition, policies and interventions can improve health by targeting factors related to individuals and their environments, including access to quality health care."); Magnusson, supra note 26, at 572 ("The modern paradigm for understanding the determinants of health and illness (both communicable and non-communicable) calls attention to a cascading set of influences. These range from 'upstream' social, economic, and environmental factors all the way down to individual behaviors, clinical interventions, and genetics.").

57. See Marmot, supra note 55, at S16 (noting that not just money, but also culture and other factors lead to a "short life expectancy").

58. See id. (noting that "we need to go beyond absolute measures of income to understand the relationship between social position and health"); WORLD Health ORganization (WHO), Commission ON THE Social Determinants OF HEALTH, Closing the Gap in a Generation: Health Equity Through Action on the Social Determinants of Health (2008), available at http://whqlibdoc.who.int/ publications/2008/9789241563703_eng.pdf (explaining how daily living conditions, including the effect of power, money, and resources affects health).

59. See, e.g., ELIZABETH S. MOORE, IT'S ChILD'S PLAY: ADVERGAMING AND THE ONLINE MARKETING OF FOOD TO CHILDREN-REPORT (2006), available at http://www.kff.org/entmedia/upload/7536.pdf; CTR. FOR SCI. IN THE PUB. Interest, Pestering Parents: How Food Companies Market Obesity to 
environment saturated with unhealthy options that are cheaper and more readily accessible than healthy choices. ${ }^{60}$ Not getting enough physical exercise is not simply a personal failure, it is a behavior influenced by a built environment that discourages walking for transportation and provides few opportunities for active entertainment. ${ }^{61}$ In turn, the information, food, and built environments that one lives and works within are dependent upon underlying social and economic factors. Poor neighborhoods have more fast food establishments and fewer full-service grocery stores than middle-income neighborhoods. ${ }^{62}$ Children from lowincome families are more likely to live in communities where

CHILDREN (2003), available at http://www.cspinet.org/new/pdf/pages_from_ pestering_parents_final_pt_1.pdf (explaining that food companies advertise to children through the television and through the internet); CTR. FOR SCI. IN THE Pub. Interest, Pestering Parents: How Food Companies Market Obesity to CHILDREN (2003), available at http://www.cspinet.org/new/pdf/pages_from pestering_parents_final_pt_1.pdf (noting that it is difficult for parents to compete with the advertisements on television, in magazines, at school, and other sources that affect what their children want to eat); David Ashton, Food Advertising and Childhood Obesity, 97 J. ROYAL SOC'Y MED. 51, 51 (2004) ("[A]dvertising to children does have an adverse effect on food preferences, purchasing behaviour and consumption.").

60. See, e.g., Paul Diller \& Samantha Graff, Regulating Food Retail for Obesity Prevention: How Far Can Cities Go?, 39 J.L. MeD. \& Ethics 89, 89 (2011) ("Regulating retail food establishments can be a powerful tool for improving a community's food environment, especially in low-income 'food desserts'-areas that lack full-service supermarkets and restaurants and are saturated with fast-food restaurants and liquor stores."); Adam Drewnowski, Obesity and the Food Environment: Dietary Energy Density and Diet Costs, 27 AM. J. Preventative MED. 154, 154 (2004) (explaining that foods that are higher in calories and fat saturated foods tend to be cheaper).

61. See, e.g., Wendy C. Perdue, Obesity, Poverty, and the Built Environment: Challenges and Opportunity, 15 GeO. J. ON POVERTY L. \& POL'Y 821,825 (2008) ("Access to healthy food, sidewalks and land use patterns that facilitate walking, and ample recreation facilities are all environmental characteristics that impact obesity-causing behaviors."); Montrece McNeil Ransom et al., Pursuing Health Equity: Zoning Codes and Public Health, 39 J.L. MED. \& ETHICS 94, 95 (2011) ("[C]ommunity design intricacies and urban planning processes can lead to environments that either reduce or exacerbate health inequities.").

62. See, e.g., Neissa Smith, Eatin' Good? Not in This Neighborhood: A Legal Analysis of Disparities in Food Availability and Quality at Chain Supermarkets in Poverty-Stricken Areas, 14 MICH. J. RACE \& L. 197, 197 (2009) ("One reason for this struggle is the tendency of chain supermarkets to provide a limited selection of goods and a lower quality of goods to patrons in less affluent neighborhoods."). 
public parks and playgrounds are in disrepair and where the threat of violence keeps people indoors. ${ }^{63}$ These are only a few of the factors that determine supposedly personal choices, and obesity is only one of the many health outcomes in which a social gradient is in evidence. Public health science is demonstrating that "[t]he poor sicken more than the rich not simply because they encounter more microbes or engage in less healthy behavior-their exposure and their behavior have social roots." 64 The question is whether the politics of public health will keep up with the science. ${ }^{65}$

The ecological model of health has opened up expansive new frontiers for public health law. ${ }^{66}$ As public health scientists and practitioners began to explore options for altering our environments in ways that promote population health, they found that they once again had a need for lawyers and policymakers. Public health law began to evolve from the law of communicable disease control towards a much broader discipline defined by Gostin in 2000 as:

the study of the legal powers and duties of the state to assure the conditions for people to be healthy (e.g., to identify, prevent, and ameliorate risks to health in the population) and the limitations on the power of the state to constrain the autonomy, privacy, liberty, proprietary,

63. See, e.g., Gary Bennet et al., Safe to Walk?: Neighborhood Safety and Physical Activity Among Public Housing Residents, 4 PLOS MED. 1599, 1605 (2007) ("Our data provide preliminary, albeit cross-sectional, evidence that perceived neighborhood safety may serve as a barrier to physical activity in lowincome settings."); Dustin Duncan et al., Association Between Neighborhood Safety and Overweight Status Among Urban Adolescents, 9 BMC PuBLIC HEALTH 289,290 (2009) ("Neighborhood safety may be an important contributor to overweight, as it has been theorized that fear of violence and crime in the immediate social environment is a barrier to physical activity and a facilitator of sedentary behavior (two well-established predictors of overweight).").

64. Gostin et al., supra note 23, at 75.

65. See Mark A. Hall, The Scope and Limits of Public Health Law, 46 PERSP. BIOLOGY \& MED. S199, S199 (2003) (exploring "the proper scope of public health legal authority in response to compelling scientific evidence about the social determinants of health").

66. See Magnusson, supra note 26, at 574 ("The recognition that health is ... the product of the interaction of environmental, socioeconomic, behavioral, and biological factors, partially modified by medical interventions--opens up a variety of possibilities for public health policy."). 
or other legally protected interests of individuals for the protection or promotion of community health. ${ }^{67}$

Gostin's influential treatise refers to "law as a tool for the public's health" and identifies multiple models for legal intervention that range far beyond the body of public health statutes and regulatory codes. ${ }^{68}$ Gostin's text reflects developments in public health practice. Public health advocates are working to develop and implement innovative, evidence-based regulatory solutions to a wide range of health problems. ${ }^{69}$ They are also increasingly involved in the development of groundbreaking litigation strategies. ${ }^{70}$

67. Gostin, Public Health LaW: Power, Duty, Restraint 4 (1st ed. 2000).

68. Gostin, supra note 12 , at 21.

69. See, e.g., Michael F. Jacobson \& Kelly D. Brownell, Small Taxes on Soft Drinks and Snack Foods to Promote Health, 90 AM. J. PUB. Health 854, 854 (2000) ("To compensate for an unhealthy food environment, it has been suggested that foods high in calories, fat, or sugar be subjected to special taxes and that the cost of healthful foods, such as fruits and vegetables, be subsidized."); Kelly D. Brownell \& T.R. Frieden, Ounces of Prevention-the Public Policy Case for Taxes on Sugared Beverages, 360 NEw ENG. J. MEd. 1805, 1805 (2009).

A penny-per-ounce excise tax could reduce consumption of sugared beverages by more than $10 \%$. It is difficult to imagine producing behavior change of this magnitude through education alone, even if government devoted massive resources to the task. In contrast, a sales tax on sugared drinks would generate considerable revenue, and as with the tax on tobacco, it could become a key tool in efforts to improve health.

T. Giang et al., Closing the Grocery Gap in Underserved Communities: The Creation of the Pennsylvania Fresh Food Financing Initiative, 14 J. PUB. HEaLTH MGMT. \& Prac. 272, 275 (2008) (discussing " $t$ t]he Fresh Food Financing Initiative... [which] works to meet the financing needs of supermarket operators that plan to operate in underserved communities where infrastructure costs and credit needs cannot be filled solely by conventional financial institutions"); Melissa Neiman, Motorcycle Helmet Laws: The Facts, What Can be Done to Jump-start Helmet Use, and Ways to Cap Damages 11 J. HEALTH CARE L. \& POL'Y 215, 232-35, 238-40, 243-48 (2008) (encouraging courts and legislatures to create a duty for motorcyclists to wear helmets); Eric P. Lynch, Federal Gun Storage Legislation: Will this Keep Guns Out of the Hands of our Children, 16 J. CONTEMP. HEALTH L. \& Pol'Y 211, 230-31 (1999) (analyzing The Child Firearm Access Prevention Act, which "insure[s] the safe storage of firearms in those states that have not passed such laws"); James Hodge, Jr. \& Gabriel Eber, Tobacco Control Legislation: Tools for Public Health Improvement, 32 J.L. MED. \& ETHICS 516, 520-22 (2004) (arguing for the implementation of effective tobacco control policies).

70. See Peter Jacobson \& Soheil Soliman, Litigation as Public Health 


\section{B. The Emerging Critique of Public Health Law's Expanding Scope}

Criticism of the new public health law was to some extent inevitable. As Roger Magnusson has explained, "[t]he use of law as a policy tool to respond comprehensively to environmental exposures, unhealthy lifestyles, and accidental injuries threatens to impinge on the interests of a wide variety of industries, and to significantly expand sites for state intervention." 11 As Lawrence Gostin and Gregg Bloche have put it, "The 'new' public health has raised political conservatives' ire... by extending its reach beyond the traditional domain of infectious disease to social and economic influences on population-wide health. In doing so it has inquired into... causal connections between ill-health and such powerful institutions as tobacco companies, industrial polluters, firearm manufacturers, and fast-food chains." ${ }^{2}$ Certainly, the critical response to new public health is motivated in part by material interests. ${ }^{73}$ But it also arises out of deep-seated philosophical and cultural views about whether the degree of government intrusion supported by decisions like Jacobson $v$. Massachusetts is justified when applied to noncommunicable disease threats and the social determinants of health.

On a philosophical level, the debate over new public health law arises out of a tension between public health's communitarian foundations and the liberal foundations of American law and policy. Thaddeus Pope, a health law scholar trained in philosophy, has articulated the tension in terms of core values: "[l]iberalism demands that liberty limitation be carefully,

Policy: Theory or Reality?, 30 J.L. MED. \& ETHICS 224, 224 (2002) ("In recent years, the most ardent proponents of litigation as public policy have been public health advocates.").

71. Magnusson, supra note 26 , at 572.

72. Lawrence O. Gostin \& M. Gregg Bloche, The Politics of Public Health: A Response to Epstein, 46 PERSP. BIOLOGY \& MED. S160, S172 (2003).

73. The industries mentioned by Gostin and Bloche have pumped significant funds into mounting public relations campaigns opposing measures such as taxes on sugared beverages. See Joey Peters, Soda Taxes Fizzle in Wake of Industry Lobbying, MCCLATCHY TRIBUNE, July 13, 2010, available at http://www.washingtonpost.com/wp-dyn/content/article/2010/07/13/AR20100713 03494.html ("In every state where a soda-tax plan has been proposed, it's been met with a heavily funded campaign from the beverage lobby to oppose any type of increase."). 
narrowly, and thoroughly justified. Communitarianism, in contrast, holds that individual rights and social responsibilities are equivalent, and that liberty and the common good have equal standing."74 The dominant philosophy of American law is liberalism-"a language centered on the values of freedom, selfdetermination, self-discipline, personal responsibility, and limited government." 75 Public health, on the other hand, "is fundamentally an effort to promote... shared goals" of "reducing disease, saving lives, and promoting good health," and is thus "a species of communitarianism." "Broadly conceived, public health offers a distinctly different "language" for talking about "how a society balances considerations of personal responsibility and social accountability in public policies that impact health."77

On a cultural level, the expansion of public health law highlights a central tension between the behavioral model, which supported a cultural norm of personal responsibility for health behaviors, and the ecological model, which problematizes that vision and promotes public responsibility for healthy living conditions. As Gostin, Burris, and Lazzarini have noted, "seeing public health predominantly as the control of risky behavior can quickly become, for cultural and political reasons, a warrant for treating health entirely as a matter of personal responsibility."78 The behavioral model's notion of health as a matter of personal responsibility has been so influential that critics of the new public health law have adopted it implicitly. Critics of the "revolution" in public health have wrongly posited a shift from

74. Pope, supra note 9.

75. Id.; see also Scott Burris, The Invisibility of Public Health: PopulationLevel Measures in a Politics of Market Individualism, 87 AM. J. PUB. HEALTH 1607, 1608 (1997) ("[T]o accept the rhetorical structure of market individualism is to accept a political language that has no words for public health.").

76. Introduction: Ethical Theory and Public Health, in FUTURE OF PUBLIC HEALTH, supra note 19 , at 20.

77. Lawrence Wallack \& Regina Lawrence, Talking About Public Health: Developing America's "Second Language," 95 AM. J. PUB. HEALTH 567, 567 (2005).

78. Gostin et al., supra note 23, at 72 (emphasis added); see also PARMET, supra note 22 , at 111 ("If individuals are assumed to be the masters of their own health, and if populations are viewed as mere aggregations of individuals, then the health of populations can be seen as a function of individual choices."). 
the "old" agent model to the "new" ecological model. Ironically, this oversimplified story ${ }^{79}$ both omits and tacitly adopts the behavioral model's view that law has little relevance to modern public health problems. It also ignores the extent to which the ecological model represents a return to the basic approach of the Sanitarians-who argued that health issues "were societal and that the appropriate measures thus had to be applied across society." 80 Although the agent model drew resources and attention away from the social reform movement of the Sanitarians, ${ }^{81}$ it was the behavioral model that solidified the belief that "lifestyle" diseases were a matter of personal responsibility beyond the reach of public health law. ${ }^{82}$ The ecological model vindicates this earlier cultural shift by associating health outcomes with structural factors that constrain individual choices.

Recently, a handful of legal scholars-including Richard Epstein, ${ }^{83}$ Mark Hall, ${ }^{84}$ Mark Rothstein, ${ }^{85}$ and Thaddeus

79. See William J. Novak, Private Wealth and Public Health: A Critique of Richard Epstein's Defense of the "Old" Public Health, 46 PERSP. BIOLOGY \& MED. S176 (2003) (offering an "alternative history of public health regulation in the United States" that "emphasizes the close links between public health law and the larger history of liberalism, state-building, and American constitutional development").

80. See Awofeso, supra note 26, at 705 ("[P]ublic health seems to have come full circle."). Compare Susser \& Susser, supra note 26, at 669, with Michael Marmot, Social Determinants of Health Inequalities, 365 THE LANCET 1099, 1103 (2005) ("[I]f the major determinants of health are social, so must be the remedies.").

81. See Susser \& Susser, supra note 26, at 670 ("[T]he epidemiology of populations and environmental exposures, and the social dynamics of disease that had followed from the miasma theory went into decline, replaced by a focus on control of infectious agents.").

82. See Magnusson, supra note 26, at 577 ("Society looks to the state to act decisively in response to risks posed by communicable diseases, contaminated food, toxic spills, and other 'externally caused threats.' But debate persists around the state's responsibility to respond to risks over which individuals are presumed to have control, including obesity, smoking, and chronic disease.").

83. Epstein, supra note 11, at S138; Richard A. Epstein, In Defense of the "Old" Public Health, 69 BROOK. L. REV. 1421 (2004) [hereinafter Epstein, In Defense of the "Old" Public Health]; Richard A. Epstein, What (Not) to Do About Obesity: A Moderate Aristotelian Answer, 93 GEo. L.J. 1361 (2005).

84. Hall, supra note 65, at S202.

85. Mark A. Rothstein, Rethinking the Meaning of Public Health, J.L. MED. \& ETHICS 144 (2002) [hereinafter Rothstein, Rethinking the Meaning of Public 
Pope ${ }^{86}$-have articulated coherent and principled criticisms of the expanding scope of public health. Although each scholar has approached the issue from his own perspective, ${ }^{87} \mathrm{I}$ detect an overarching project in their work as a whole. For the purposes of

Health]; Mark A. Rothstein, The Limits of Public Health: A Response, 2 PUB. Health ETHICs 84 (2009) [hereinafter Rothstein, The Limits of Public Health].

86. Pope, supra note 9.

87. The four critics of new public health law diverge in their reasons for being skeptical of its expanding scope. Epstein generally argues against all social and economic regulation unless it is rigorously justified in terms of market failure. See, e.g., Richard Eptstein, Throttled by Compliance, DEFINING IDEAS (Mar. 2, 2011), http://www.hoover.org/publications/defining. ideas/article/69086 (last visited Jan. 28, 2012) (arguing that "feckless regulations" will stymie innovation) (on file with the Washington and Lee Law Review). In contrast, Hall and Rothstein have each indicated that they generally support the social agenda promoted by social epidemiology, but feel that this agenda should not be co-opted by public health. See Hall, supra note 65, at S208

Beyond the public health arena, there are other good reasons for the government to pursue the more general aims of education, taxation, regulation, and redistribution, but these are broader social and economic policies or they belong to legal realms other than health. Public health advocates can be commended for calling our attention to the health implications of social disparities, but health promotion should not be the primary objective of corrective measures.

See also Rothstein, The Limits of Public Health, supra note 85, at 86 ("[C]oncerns about social justice should play a part in priority setting for public health. My point is simply that resolution of underlying socioeconomic and political problems is beyond the domain of public health."). Their concerns are civil libertarian in nature. See Hall, supra note 65, at S207 (noting that public health interventions to improve basic sanitation, living, and working conditions, including modern environmental and occupational health regulations are less problematic because "these measures affect primarily only property or economic interests, not personal liberty"); Rothstein, The Limits of Public Health, supra note 85 , at 85

One of the main reasons that I support a narrow definition of public health is that public health laws give public health officials a range of coercive powers to protect the population. Unless the scope of permissible governmental action is carefully circumscribed, there is a threat to civil liberties by governmental confiscation of property, restraint on the movement of individuals, mandating of medical examinations and similar measures.

Pope's view is more accommodating. He generally agrees with the agenda of new public health law, but feels that this agenda can be justified only in terms of hard paternalism and that efforts to justify it on other grounds-for example in terms of the aggregate costs that unhealthy lifestyles impose on society-are dishonest. For this reason, Pope is perhaps less a subscriber to the liberal critique than a describer of it. 
this Article, I will characterize this project as an emerging liberal (in the classical sense) critique of the new public health.

The liberal critics have argued for a disconnect between public health science and practice. Hall and Epstein begin from the proposition that regardless of the validity of social epidemiology as a scientific matter, it does not necessarily follow that state authority to intervene "under the banner of public health" should be expanded.88 Epstein draws a distinction between "the conception of public health that is internal to the public health discipline, and the conception of public health as it has been understood outside the public health field by historians and lawyers who are interested in defining the appropriate use and limitations of the state power of coercion." 89 Similarly, Hall stresses the need "to more clearly differentiate between public health analysis and public health authority." He seeks to divide public health into two "broad responsibilities: (1) advancing understanding and knowledge of the causes and patterns of health conditions in society; and (2) eliminating threats to public health. The first is the domain of public health as a scientific discipline. The second is the domain of public health law." ${ }^{90}$ Hall's "central point" is that "public health law is much more limited than public health science." 91

These critics note with considerable wariness that in the domain of law, designating a problem as "public" changes the rules of the game. ${ }^{92}$ Epstein has argued that by labeling health behaviors like diet, exercise, smoking, and tanning as "public health" problems, we trigger legal doctrines that privilege heavyhanded state intervention over protection of individual rights. "[T] he case for government intervention ... gets that extra boost

88. Epstein, supra note 11, at S154.

89. Id. at $\mathrm{S} 138$.

90. Hall, supra note 65 , at S202.

91. Id.

92. See Magnusson, supra note 26, at 571 ("Debate about [the] goals and definitions [of public health law] reflects competing claims about the boundaries for the legitimate exercise of political and administrative power."); Hall, supra note 65, at S202 ("These definitional boundaries between public health law and public health science] matter a great deal because the law operates through categories, and classification has huge effects on how legal issues are analyzed."). 
of legitimacy" when framed as a public health issue ${ }^{93}$ Rothstein has offered perhaps the most eloquent statement of this position: "The broad power of government to protect public health includes the authority to supersede individual liberty and property interests in the name of preserving the greater public good. It is an awesome responsibility, and therefore it cannot and must not be used indiscriminately." 94 Ultimately, then, the debate over the legitimate scope of public health law is a debate over the meaning of the "public" as a justification for state intervention. Are noncommunicable disease threats and the social determinants of health properly understood as public health problems?

\section{Public Nuisance Law}

This Article responds to the emerging liberal critique of new public health law by linking it to a particular doctrinal debate over the proper meaning of the "public" that has arisen in the context of public nuisance litigation. Public nuisance law and public health law share a common heritage in the police power of the state. ${ }^{95}$ At its core, public nuisance is a tool for addressing

93. Epstein, In Defense of the "Old" Public Health, supra note 83, at 1424.

94. Rothstein, Rethinking the Meaning of Public Health, supra note 85, at $148-49$.

95. See Wendy E. Parmet, Legal Rights and Communicable Disease: AIDS, the Police Power and Individual Liberty, 14 J. Health PoL. Pol'y \& L. 741, 743 (1989).

In American jurisprudence the public's interest in preserving health was embodied in the concept of the 'police power,' a term that has lost much of its early meaning. The concept of the police power appears to have its roots in the law of nuisance and the common law principle that property rights are limited to the extent that they injure others. Thus the public, acting through the state, could regulate the rights of real property or contract to protect the public health and safety. More importantly, basic rights of property were limited by the needs of the public.

Some have suggested that the public nuisance cause of action, at least when brought by state and local government officials suing in parens patriae, is not properly understood as a tort at all, but is more closely related to the state's exercise of its police power. See, e.g., Thomas Merrill, Is Public Nuisance a Tort? 4 J. TORT L. 1 (2011); Karol Boudreaux \& Bruce Yandle, Public Bads and Public Nuisance: Common Law Remedies for Environmental Decline, 14 FORDHAM ENVTL. L.J. 55, 62 (2002) ("In public nuisance cases involving a private plaintiff, the action is in tort. These cases are conceptually different from a public 
public bads. Its central element is an "unreasonable interference with a right common to the general public," including "interference with the public health, the public safety, the public peace, the public comfort or the public convenience." ${ }^{96}$ It is a very old cause of action ${ }^{97}$ that advocates have made new again by applying it to some of the most complex public health and environmental ${ }^{98}$ problems of our time: the costs of tobacco use,

nuisance brought by the sovereign, which is more analogous to an exertion of the police power of the state, as noted above, rather than tort."). Like public nuisance law, early manifestations of public health law were focused on the state's police power to limit property rights. See Robyn Martin, Domestic Regulation of Public Health: England and Wales, in LAW AND THE PUBLIC DIMENSION OF HEALTH 75, 79 (Robyn Martin \& Linda Johnson eds., 2001) (describing longstanding English public health legislation, which "does not have as its primary focus the promotion of health, nor does it particularly address the causes of ill health. The concern is with inadequate premises, on an understanding that ill health results from identifiable bodies escaping from a physical source").

96. RESTATEMENT (SECOND) OF TORTS $\S 821 \mathrm{~B}$ (1979). It is worth noting here that public nuisance law does not create an affirmative right to public health such as would create a governmental obligation of fulfillment. Rather, it recognizes a negative right to be free from private interference with the public's health. This non-interference right is, however, intimately connected to the governmental obligation to protect the public's health.

97. The modern private nuisance cause of action originated as one of the three ancient assizes in twelfth-century England-alongside trespass and disseisin-which a private landowner could use to vindicate his property rights. The modern public nuisance cause of action has a distinct, but equally venerable pedigree. It also originated in twelfth-century England in the doctrine of purprestures-whereby the Crown penalized public wrongs as criminal infringements on the rights of the sovereign. Early nuisances generally involved actions that obstructed public roads or watercourses, or made them hazardous. See C.H.S. Fifoot, History aND SOURCES OF THE COMMON LAW: TORT AND CONTRACT 3-5 (1949) (describing the process by which nuisance laws were historically enforced); F.H. Newark, The Boundaries of Nuisance, 65 L.Q. REV. 480,481 (1949) (tracing the roots of nuisance in the common law). The early criminal writ also allowed for "incidental civil relief." William L. Prosser, Private Action for Public Nuisance, 52 VA. L. REv. 997, 997-98 (1966); Eric Kintner, Note, Bad Apples and Smoking Barrels: Private Actions for Public Nuisance Against the Gun Industry, 90 IowA L.R. 1163, 1188-89 (2005) (citing Prosser, noting that an officer of the Crown could initiate these early nuisance actions).

98. See generally Joseph L. SaX et al., Creative Common Law Strategies FoR Protecting THE ENVIRONMENT xix (Clifford Rechtschaffen \& Denise Antolini eds., 2007) (describing "how committed and creative lawyers in the first decade of the new century have reengineered the old causes of action to make them potent new tools for dealing with some of the gravest and most persistent environmental problems we face"). 
gun violence, the contamination of our housing stock with lead paint, and climate change. In a sense, the industry-wide public nuisance litigation of the 1990 s and 2000 s can be viewed as an early manifestation of the new public health law movement. ${ }^{99}$ While Hall, Epstein, Pope, and Rothstein have focused on what happens "When Epidemiologists Become Lawmakers,"100 public nuisance litigation to address product-caused harms might be understood as what happens "When Epidemiologists Become Litigators." These new applications have regenerated an old debate over the legitimate uses of public nuisance law. ${ }^{101}$ Most courts have been anxious to prevent these claims from going forward and they have sought to do so by tethering the cause of action using a wide range of procedural and substantive doctrines. This Article focuses on the substantive dilemma at the heart of these cases: can the harm to health and welfare caused

99. Cf. David Kairys, The Governmental Handgun Cases and the Elements and Underlying Policies of Public Nuisance Law, 32 CoNN. L. REV. 1175, 1178 (2000) [hereinafter Kairys, Underlying Policies] ("Public nuisance is the only tort designed and equipped to protect the public from activities or conduct that is incompatible with public health, safety, or peace."); DONALD G. GIFFoRD, SUING THE Tobacco AND LEAd Pigment IndUSTRIES: Government Litigation as Public Health Prescription (2010) (identifying public nuisance litigation against product manufacturers as a form of public health litigation).

100. Hall, supra note 65, at S202.

101. Public nuisance has long been ridiculed by courts and commentators as a "monster that would devour in one gulp the entire law of tort," Tioga Public Sch. Dist. v. U.S. Gypsum Co., 984 F.2d 915, 921 (8th Cir. 1993), "the dust bin of the law," Award v. McColgan, 98 N.W.2d 571, 573 (Mich. 1959); Osborne M. Reynolds, Jr., Public Nuisance: A Crime in Tort Law, 31 OKLA. L. REv. 318 (1978), and a collection of the "rag ends of the law." Newark, supra note 97, at 482. The same anxiety is palpable in court opinions adjudicating modern public nuisance claims against product manufacturers and distributors. See, e.g., Camden County Bd. of Chosen Freeholders v. Beretta U.S.A. Corp., 273 F.3d 536 (3d Cir. 2001) ("[I]f public nuisance law were permitted to encompass product liability, nuisance law "would become a monster that would devour in one gulp the entire law of tort."); In re Lead Paint Litig., 924 A.2d 484, 494 (N.J. 2007) ("[T] permit these complaints to proceed ... would stretch the concept of public nuisance far beyond recognition and would create a new and entirely unbounded tort antithetical to the meaning and inherent theoretical limitations of the tort of public nuisance."); People ex rel. Spitzer v. Sturm, Ruger \& Co., Inc., 309 A.D.2d 91, 96 (N.Y. App. Div. 2003) ("[G]iving a green light to a common-law public nuisance cause of action today will... likely open the courthouse doors to a flood of limitless, similar theories of public nuisance ... against [these defendants and against] a wide and varied array of other commercial and manufacturing enterprises and activities."). 
by industries that manufacture and distribute dangerous products be legitimately understood as interference with a public right?

\section{A. The Doctrine of Public Nuisance}

Public nuisance is perhaps best explained by way of reference to its cousin, private nuisance. For example, the owner of a hog farm producing noxious odors and other unpleasantness gets sued by neighboring property owners who argue that their right to enjoy their own property is being infringed upon by the defendant's allegedly unreasonable use of its property. One kind of public nuisance claim is a fairly modest extension of this private nuisance doctrine. Imagine the hog farm is not just affecting its neighbors, but an entire town. At a certain point, this property-based private nuisance becomes a public one simply by virtue of the large number of people affected. ${ }^{102}$ But there is also another kind of public nuisance claim ${ }^{103}$ that does not necessarily have anything to do with the defendant's property use or the plaintiffs' property enjoyment. ${ }^{104}$ It is this broader kind of claim that has sparked most of the legal and political controversy over nuisance. ${ }^{105}$

102. See, e.g., Village of Pine City v. Munch, 44 N.W. 197, 197-98 (Minn. 1890 ) ("[A nuisance is public] if it affects the surrounding community generally or the people of some local neighborhood.").

103. Michael McBride, Critical Legal History and Private Actions Against Public Nuisances, 1800-1865, 22 CoLUM. J.L. \& Soc. PROBS. 307, 313-14 (1989) (describing two distinct types of public nuisance cases before nineteenth-century courts-those involving the infringement of public rights and those involving aggregations of injuries to private rights in land "so widespread as to be a legitimate concern of the state").

104. See City of Cincinnati v. Beretta U.S.A. Corp., 768 N.E.2d 1136, 1142 (Ohio 2002) (holding that nuisance claims are not limited to real property and can be maintained for injuries caused by a product's design, manufacturing, marketing, or sale if the defendant's conduct interfered with a common right of the general public); 58 AM. JUR. 2D Nuisances $\S 31$, at 592 (2002) ("A public nuisance, unlike a private nuisance, does not necessarily involve an interference with the use and enjoyment of land, or an invasion of another's interest in the private use and enjoyment of land, but encompasses any unreasonable interference with a right common to the general public.").

105. Of course, even the more limited doctrine of private nuisance has generated its share of controversy. So much so that in the great majority of states, our hog farm would be able to proceed with little concern for private or 
In general, a public nuisance of the broader type is defined as a substantial and unreasonable interference with a right common to the general public. ${ }^{106}$ This right is sometimes referred to as a right "of the community at large," 107 or a "public right." ${ }^{108}$ Section

public nuisance liability of the first kind. In all fifty states, "right to farm" statutes provide some degree of immunity from nuisance suits for farming operations that meet certain criteria, even where their industrial methods impose considerable burdens on the health and welfare of surrounding communities. See generally Rusty Rumley, A Comparison of the General Provisions Found in Right to Farm Statutes, 12 VT. J. ENVTL L. 327 (2011).

106. RESTATEMENT (SECOND) OF TORTS $§ 821 \mathrm{~B}$ (1979).

107. Prosser, supra note 97, at 999; see also Ozark Poultry Prods. Inc. v. Garman, 472 S.W.2d 714, 716 (Ark. 1971); Fisher v. Zumwalt, 128 Cal. 493, 49596 (Cal. 1900) (noting that public nuisance is usually limited to "an invasion of a right which is common to every person in the community") (quoting Fisher v. Zumwalt, 61 P. 82 (Cal. 1900)); see also People v. Rubenfeld, 172 N.E. 485, 486 (N.Y. 1930) (noting that to qualify as a public nuisance, "the number of persons affected need not be ... 'very great.' Enough that so many are touched by the offense and in ways so indiscriminate and general that the multiplied annoyance may not unreasonably be classified as a wrong to the community").

108. See, e.g., Ganim v. Smith \& Wesson Corp., 780 A.2d 98, 131-32 (Conn. 2001)

Nuisances are public where they violate public rights, and produce a common injury, and where they constitute an obstruction to public rights, that is, the rights enjoyed by citizens as part of the public... . If the annoyance is one that is common to the public generally, then it is a public nuisance... The test is not the number of persons annoyed, but the possibility of annoyance to the public by the invasion of its rights.

City of Phoenix v. Johnson, 75 P.2d 30, 34 (Ariz. 1938)

A nuisance is common or public when it affects the rights which are enjoyed by its citizens as a part of the public, while a private nuisance is one which affects a single individual or a definite number of persons in the enjoyment of some private right which is not common to the public ... The distinction does not arise from any necessary difference in the nature or the character of the thing which creates a nuisance, but is based on the difference between the rights affected thereby.

City of New York v. A-1 Jewelry \& Pawn, Inc., 247 F.R.D. 296, 343 (S.D.N.Y. 2007)

A public nuisance "consists of conduct or omissions which offend, interfere with or cause damage to the public in the exercise of rights common to all, in a manner such as to offend public morals, interfere with the use by the public of a public place, or endanger or injure the property, health, safety or comfort of a considerable number of persons."

(quoting Copart Indus., Inc. v. Consol. Edison Co., 362 N.E.2d 968, 971 (N.Y. 1977)). 
$821 \mathrm{~B}$ of the Second Restatement of Torts "sweeps broadly in defining a 'public right,' including 'the public health, the public safety, the public peace, the public comfort, or the public convenience." 109 In the United States, the non-property based public nuisance claim has developed into a cause of action used primarily by state and local governments ${ }^{110}$ to address the contributions of a private actor to unhealthy living conditions or other unreasonable interference with collective interests. ${ }^{111}$ In the view of its proponents, "[a] public nuisance claim is the vehicle provided by civil law for executive-branch officials to seek immediate relief to stop and remedy conduct that is endangering the public." 112 In the view of its critics, it threatens to become "a tort where liability is based upon unidentified ills allegedly suffered by unidentified people caused by unidentified products in unidentified locations."113

Public nuisance has been described by Victor Schwartz as a "super tort." 114 It triggers standards of fault and causation that

109. In re StarLink Corn Prods. Liab. Litig., 212 F. Supp. 2d 828, 848 (N.D. III. 2002) (quoting RESTATEMENT (SECOND) OF TORTS $§ 821 \mathrm{~B}(2)(a)$ ).

110. Private plaintiffs can also bring suit if they are able to satisfy the "special injury" rule. See RESTATEMENT (SECOND) OF TORTS § 821C(1) (1979) (stating that to recover damages, a private plaintiff must have "suffered harm of a kind different from that suffered by other members of the public exercising the right common to the general public that was the subject of the interference"); see also John G. Culhane \& Jean Macchiaroli Eggen, Defining A Proper Role for Public Nuisance Law in Municipal Suits Against Gun Sellers: Beyond Rhetoric and Expedience, 52 S.C. L. REV. 287, 291 (2001) (arguing that private actions for public nuisance "serve no defensible purpose and should be abolished").

111. See, e.g., City of Miami v. Coral Gables, 233 So.2d 7, 8 (Fla. Dist. Ct. App. 1970) (public nuisance action brought by Coral Gables on behalf of its citizens against air pollution from an incinerator owned and operated by Miami); Village of Wilsonville v. SCA Servs., Inc., 426 N.E.2d 824, 827 (Ill. 1981) (chemical waste disposal site alleged to be a public nuisance threatening "the health of the citizens of the village, the county, and the State"); Maryland v. Galaxy Chem., 1 ENv'T ReP. CAS. (BNA) 1660, 1661-64 (Md. Cir. Ct. 1970) (public nuisance action brought by state on behalf of neighbors exposed to air pollution from a nearby chemical plant, some of whom claimed to have been injured by its emissions of toxic fumes).

112. Kairys, Underlying Policies, supra note 99, at 1176.

113. Richard Faulk \& John Gray, Alchemy in the Courtroom? The Transmutation of Public Nuisance Litigation, 2007 Mich. ST. L. REV. 941, 98182 (2007).

114. Victor E. Schwartz \& Phil Goldberg, The Law of Public Nuisance: 
are less rigorous than those applied to personal injury claims. Public nuisance is generally understood as a form of strict (or "no fault") liability, ${ }^{115}$ at least in the context of suits brought by governmental plaintiffs. ${ }^{116}$ In recent decades, however, some courts have imposed an illegitimate fault requirement on public nuisance claims more generally.117 Although the causation requirements are technically the same for nuisance as for any other tort, the way in which a nuisance claim is framed alters the analysis. At least in theory, public nuisance plaintiffs, who are alleging harm to the public at large rather than to any particular individual or class of individuals, ${ }^{118}$ need only prove causation at the population level. ${ }^{119}$

Maintaining Rational Boundaries on a Rational Tort, 45 WASHBURN L.J. 541, 552 (2006).

115. Id. In recent decades, however, some courts have imposed a fault requirement on public nuisance claims. See Robert Abrams \& Val Washington, The Misunderstood Law of Public Nuisance: A Comparison with Private Nuisance Twenty Years After Boomer, 54 ALB. L. REv. 359, 367-74 (1990) (discussing the "improper imposition of traditional fault concepts on the law of public nuisance").

116. See Karol Boudreaux \& Bruce Yandle, Public Bads and Public Nuisance: Common Law Remedies for Environmental Decline, 14 FoRDHAM ENVTL. L.J. 55, 62-63 \& 63 n.24 (2002) (arguing that "[i]n suits brought by the sovereign, liability for public nuisance is strict, however in private action on public nuisances cases the liability is based upon the defendant's negligence" but noting that "the liability issue in public nuisance is confused").

117. See Abrams \& Washington, supra note 115, at 367-74 (discussing the "improper imposition of traditional fault concepts on the law of public nuisance").

118. Class action suits are like public nuisance suits in that they provide a means for collectivizing private claims. See Developments, The Paths of Civil Litigation, Part II: The Use of the Public Nuisance in Tort Against the Handgun Industry, 113 HARV. L. REv. 1759, 1761 n.12 (2000) (describing generally the similarity of class actions and public nuisance with regard to aggregation of claims). But class action suits are based on the aggregation of individual claims, unlike the claims at issue in public nuisance litigation, which are fundamentally collective.

119. In recent cases, however, some courts have misunderstood this point and imposed a requirement that governmental plaintiffs trace the harm from particular defendants to particular individuals. See, e.g., City of Chicago v. Am. Cyanamid Co., 823 N.E.2d 126, 134 (Ill. App. Ct. 2005) ("[P]laintiff has failed to allege causation in fact because plaintiff has not identified any specific defendant as the source of any lead pigment or paint at any particular location."); Whitehouse v. Lead Indus. Ass'n, No. Civ. A 99.5226, 2003 WL 1880120 (R.I. Super. Ct. Mar. 20, 2003); Lewis v. Lead Indus. Ass'n, 793 N.E.2d 869, 878 (Ill. App. Ct. 2003) ("[T] he plaintiffs' failure to identify the defendants 


\section{B. The Evolution of Industry-Wide Public Nuisance Litigation as a Tool for Public Health}

The great majority of public nuisance cases are of the property-based type, which involve the defendant's use of its property in a way that interferes with the rights of others. Beginning in the 1980s, however, advocates began to draw more heavily on the doctrine of "public right" nuisance, in circumstances where the harm to the public's interest is not mediated via property in the possession or control of the defendant. Advocates first experimented with this approach in the context of asbestos litigation. As asbestos building products deteriorate, they release fibers that are carcinogenic when inhaled. The dangers of asbestos became widely known in the 1980 s and 1990s as a generation of (mostly) men, exposed to the material through their work decades earlier, began to be diagnosed with a rare and lethal cancer called mesothelioma. In response, regulations were adopted requiring the removal or other abatement of asbestos in school buildings. ${ }^{120}$ Property owners became concerned about potential tort liability for allowing asbestos to deteriorate on their properties. At the same time, individual victims of asbestos-related illnesses sued the asbestos industry, though their claims were often stymied by their inability to tie the injuries of individual plaintiffs to the products of particular manufacturers. ${ }^{121}$

Eventually, public nuisance claims were filed against asbestos manufacturers by several municipalities and school districts suing in their capacity as property owners to recover abatement costs. These claims were not based on the argument that asbestos-containing buildings constituted a property-based nuisance. Rather, they claimed that the manufacture and distribution of asbestos products constituted a nuisance. ${ }^{122}$ These

who supplied the lead pigment used in the paint to which their children were exposed constituted a failure to allege facts in support of the causation element of the claim.").

120. Asbestos Hazard Emergency Response Act, 15 U.S.C. $\S \S 2641-56$ (2011).

121. See James L. Stengel, The Asbestos End-Game, 62 N.Y.U ANN. SuRv. AM. L. 223, 236 (2006) (explaining ways claimants may succeed in the absence of manufactured products or premises identification testimony).

122. Schwartz \& Goldberg, supra note 114, at 553 (citing Corp. of Mercer 
non-property-based claims were rejected by most courts. ${ }^{123}$ In Detroit Board of Education v. Celotex Corp., ${ }^{124}$ for example, the court concluded that products liability, not public nuisance, was the proper avenue for bringing such a claim and that a product could not constitute a nuisance. ${ }^{125}$ Courts also relied on the argument that nuisance liability requires that the defendant have "control" of the nuisance. ${ }^{126}$ They concluded that this element could not be established in a case against a product manufacturer because the product is in the control of another party (in these cases, the plaintiff property owners themselves) at the time that it causes harm. ${ }^{127}$

"The watershed event" for industry-wide public nuisance litigation came in the $1990 \mathrm{~s}$, when several state attorneys general added public nuisance claims to their suits against tobacco manufacturers, shortly before the Master Settlement Agreement

Univ. v. Nat'l Gypsum Co., No. 85-126-3-MAC, 1986 WL 12447, at *6 (M.D. Ga. Mar. 9, 1986)); see also City of Manchester v. Nat'l Gypsum Co., 637 F. Supp. 646, 656 (D.R.I. 1986); Town of Hooksett Sch. Dist. v. W.R. Grace \& Co., 617 F. Supp. 126, 133 (D.N.H. 1984); Cnty. of Johnson v. U.S. Gypsum Co., 580 F. Supp. 284, 294 (E.D. Tenn. 1984).

123. See Faulk \& Gray, supra note 113, at 957-58 (citing City of San Diego v. U.S. Gypsum Co., 30 Cal. App. 4th 575 (Cal. Ct. App. 1994)); Tioga Pub. Sch. Dist. No. 15 v. U.S. Gypsum Co., 984 F.2d 915, 920-21 (8th Cir. 1993); Cnty. of Johnson, 580 F. Supp. at 294 ("[A]llowing ... this action under a nuisance theory would convert almost every products liability action into a nuisance claim."); Detroit Bd. of Educ. v. Celotex Corp., 493 N.W.2d 513, 521 (Mich. Ct. App. 1992) (stating that "manufacturers, sellers, or installers of defective products may not be held liable on a nuisance theory for injuries caused by [a product] defect"); Corp. of Mercer Univ. v. Nat'l Gypsum Co., No. 85-126-3-MAC, 1986 WL 12447, at *6 (M.D. Ga. Mar. 9, 1986) (noting that even if asbestos were considered a nuisance, "[ $\mathrm{t}]$ he 'nuisance' creating property ... was in possession and control of the plaintiff from the time it purchased the asbestos-containing products"); see also Nat'l Gypsum Co., 637 F. Supp. at 656; W.R. Grace \& Co., 617 F. Supp. at 133.

124. Detroit Bd. of Educ. v. Celotex Corp., 493 N.W.2d 513 (Mich. Ct. App. 1992).

125. See id. at 520 (noting that the case is clearly a products liability action and may not be characterized as a nuisance).

126. See Peter Tips, Controlling the Lead Paint Debate: Why Control is Not an Element of Public Nuisance, 50 B.C. L. REv. 605, 607 (2009) (noting that courts sometimes impose a control element to public nuisance claims).

127. See, e.g., Camden Cnty. Bd. of Chosen Freeholders v. Beretta U.S.A. Corp., 273 F.3d 536 (3d Cir. 2001); Rhode Island v. Lead Indus. Ass'n, 951 A.2d 428 (R.I. 2008). 
(MSA) was reached. ${ }^{128}$ Most of these suits did not produce a court ruling prior to the MSA, but one federal district court did rule on a public nuisance claim in Texas $v$. American Tobacco Co. ${ }^{129}$ The plaintiffs framed the claim in terms of intentional interference with "the public's right to be free from unwarranted injury, disease, and sickness" and alleged that the defendants had "caused damage to the public health, the public safety, and the general welfare of the citizens." 130 The federal district court dismissed the claim on the grounds that it was unsupported by Texas case law. Overall, however, the MSA was hailed as an enormous achievement by the state attorneys general. ${ }^{131}$ Many have pointed to this practical success as generating a groundswell of interest in public nuisance litigation, even though it had not produced any court opinions supporting its use. ${ }^{132}$

Litigation against firearms manufacturers and distributors provided the first opportunity for significant numbers of courts to adjudicate public nuisance claims based on products inherently harmful to the public's health and safety. Products liability had long been an avenue (though often a difficult one)

128. Schwartz \& Goldberg, supra note 114 , at 554. Others dispute the importance of public nuisance claims in turning the tide of tobacco litigation. See, e.g., Faulk \& Gray, supra note 113, at 958 (noting that "many ... wrongly credit the use of public nuisance claims with turning the tide against the tobacco industry" and arguing that "[t]he real turning point [was] the disclosure that tobacco companies concealed documents showing the addictive nature of smoking, and the nationwide coordinated effort of state-sponsored lawsuits"). In any case, David Kairys has said that he saw the state tobacco litigation as a model for addressing the role of manufacturers and distributors to contributing to the problem of rampant gun violence. See David Kairys, The Origin and Development of the Governmental Handgun Cases, 32 CoNN. L. REv. 1163, 1172 (2000) [hereinafter Kairys, Origin and Development].

129. Texas v. Am. Tobacco Co., 14 F. Supp. 2d 956 (E.D. Tex. 1997) (discussed in Schwartz \& Goldberg, supra note 114, at 554).

130. Id. at 972 .

131. Press Release, Dep't of Law, State of Georgia, Statement of Attorney General Thurbert Baker Regarding Georgia's Tobacco Litigation (Nov. 20, 1998), available at http://aw.ga.gov/00/press/detail/0,2668,87670814_89151348_ $89525625,00 \mathrm{html}$ (on file with Washington and Lee Law Review).

132. See Schwartz \& Goldberg, supra note 114, at 554-55 ("Given the sheer size of the award and resulting attorneys' fees, it is not surprising that, since the MSA, government and plaintiffs' lawyers have attempted to apply public nuisance theory against many other industries of product manufacturers."). 
for plaintiffs suing the firearms industry based on the harms associated with gun violence, ${ }^{133}$ but this litigation was different. The public nuisance claims against gun manufacturers were not based on allegations that guns were defective products, nor were the plaintiffs alleging that the manufacture of guns by itself constituted a nuisance.

Instead, the plaintiffs argued that specific distribution practices contributed to a public nuisance by facilitating an illegal market for guns. Manufacturers and wholesale distributors were alleged to contribute to the nuisance through two principal means: First, by continuing to sell to a small number of distributors that were known to be responsible for a vastly disproportionate share of guns used in crime. Second, by knowingly distributing more guns to areas with loose gun laws that were geographically close to areas with strict gun laws. ${ }^{134}$ Although the majority of these suits were unsuccessful, 135 a few courts allowed them to proceed to trial. ${ }^{136}$ Those that did typically followed the plaintiffs' lead in

133. See Thomas F. Segalla, Governmental and Individual Claims in Gun Litigation and Coverage: Where to Go from Here?, in INSURANCE Coverage in the New Millennium 363 (ALI-ABA Course of Study 2000).

134. Kairys, Origin and Development, supra note 128, at 1171-72; see also City of Gary ex rel. King v. Smith \& Wesson Corp., 801 N.E.2d 1222, 1235 (Ind. 2003) ("The City has alleged that (1) dealers engage in illegal sales, and (2) the distributors and manufacturers know of their practice and have it within their power to curtail them but do not do so for profit reasons."). Plaintiffs in these cases submitted evidence that the "movement of guns from the industry's lawful distribution channels into the illegal market" was discussed in industry meetings and that the industry has "long known that greater industry action to prevent illegal transactions is possible and would curb the supply of firearms to the illegal market." Kintner, supra note 97, at 1187 (quoting Robert Ricker).

135. See, e.g., City of Philadelphia v. Beretta U.S.A. Corp., 277 F. $3 \mathrm{~d}$ 415, 421 (3d Cir. 2002) (dismissing public nuisance claims under Pennsylvania law); Camden Cnty. Bd. of Chosen Freeholders v. Beretta U.S.A. Corp., 273 F.3d 536, 540 (3d Cir. 2001) (dismissing public nuisance claims under New Jersey law); Ganim v. Smith \& Wesson Corp., 780 A.2d 98, 133 (Conn. 2001) (dismissing public nuisance claims); Penelas v. Arms Tech., Inc., 778 So.2d 1042, 1045 (Fla. Dist. Ct. App. 2001) (dismissing public nuisance claims); City of Chicago v. Beretta U.S.A. Corp, 821 N.E.2d 1099, 1111 (Ill. 2004) (dismissing public nuisance claims); People ex rel. Spitzer v. Sturm, Ruger \& Co., 761 N.Y.S.2d 192 (App. Div. 2003) (dismissing public nuisance claims).

136. See City of Gary ex rel. King, 801 N.E.2d at 1232 (holding that plaintiff's allegations were sufficient to allege an unreasonable chain of distribution of handguns sufficient to give rise to a public nuisance 
focusing on the characterization of the defendants' particular marketing and distribution practices, and not the products themselves, as contributing to a nuisance. For example, the Ninth Circuit held that a nuisance claim brought by a group of private plaintiffs was "not about the manufacture or distribution of a defective or properly functioning product... but rather allege[d] affirmative conduct on the part of manufacturers and distributors that fosters" a nuisance. ${ }^{137}$ Similarly, the Supreme Court of Ohio emphasized the argument that the defendants "control the creation and supply of [the] illegal, secondary market for firearms, not the actual use of the firearms that cause injury." 138 However, this approach was far from universally successful. Ultimately, the litigation was effectively cut off by Congress via the Protection of Lawful Commerce in Arms Act. ${ }^{139}$ The Act precluded tort liability for firearms manufacturers, distributors, and dealers based on criminals' unlawful use of guns. It also called for the immediate dismissal of pending suits. ${ }^{140}$

A couple of years into the firearms litigation, advocates sought to use a similar strategy against the lead paint and pigment industry in several states. ${ }^{141}$ When lead paint deteriorates, it produces dust and flakes that can easily be ingested by small children. Ingestion of lead, even in small quantities, during the early years of life when children's brains are developing rapidly has been associated with "measurable changes in children's mental development and behavior"

generated by defendants); City of Boston v. Smith \& Wesson Corp., No. 1999-02590, 2000 Mass. Super. Ct. LEXIS 352, at *63-64 (July 13, 2000) ("To be sure, the legal theory is unique in the Commonwealth but ... that is not reason to dismiss at this stage of the proceedings."); City of Cincinnati v. Beretta U.S.A. Corp., 768 N.E.2d 1136, 1136 (Ohio 2002) (allowing a public nuisance claim to proceed).

137. Ileto v. Glock, Inc., 349 F.3d 1191, 1211 (9th Cir. 2003).

138. Cincinnati, 768 N.E.2d at 1143.

139. Protection of Lawful Commerce in Arms Act, Pub. L. No. 109-92, 119 Stat. 2095 (2005).

140. Id.

141. Faulk \& Gray, supra note 113, at 1009-14 (describing suits in Wisconsin, California, Rhode Island, and New Jersey); Schwartz \& Goldberg, supra note 114 , at 559 (describing the partnership between the Rhode Island Attorney General's office and private, contingency-fee counsel). 
including "hyperactivity; deficits in fine motor function, handeye coordination, and reaction time; and lowered performance on intelligence tests." 142 Although the link between lead paint and childhood lead poisoning was established more than a century ago, ${ }^{143}$ it wasn't until 1978 that lead paint was banned in the United States ${ }^{144}$ and much of the housing stock in the United States pre-dates the ban. ${ }^{145}$ Although average blood lead levels (BLLs) among Americans declined rapidly in the years immediately following bans on lead in gasoline and paint, approximately $2.2 \%$ of children between the ages of one and five still have BLLs associated with significant health impacts. ${ }^{146}$

Advocates had attempted to use a variety of legal strategies to require - and in some cases subsidize-the abatement of lead paint in housing. ${ }^{147}$ They also filed lawsuits on behalf of individual children with elevated BLLs, but these proved even more difficult than asbestos suits. Because there is no "signature" injury that is linked to lead exposure in the way that mesothelioma is linked to asbestos, establishing causation was particularly difficult. ${ }^{148}$ Reduced intellectual capacity and

142. National Institutes of Health, National Institutes of Environmental Health Sciences, Lead (Aug. 29, 2011), http://www.niehs.nih.gov/health/ topics/agents/lead/ (last visited Jan. 28, 2012) (on file with the Washington and Lee Law Review).

143. Child lead poisoning was first diagnosed in 1897 and was linked to lead-based paints in 1904. GOLDFRANK, GOLDFRANK's TOXICOLOGIC EMERGENCIES 1310 (8th ed. McGraw-Hill Professional 2006). A handful of European countries banned the use of interior white-lead paint in 1909. The League of Nations adopted a similar ban in 1922. GILBERT, SG \& WEISS, B, A Rationale for Lowering the Blood Lead Action Level from 10 to $2 \mathrm{microg} / \mathrm{dL}$, 27 NEUROTOXICOLOGY 693, 695 (2006).

144. Lead-Based Paint Poisoning Prevention Act, 42 U.S.C. $\$ 4831$ (2006).

145. Joseph Pargola, Childhood Lead Poisoning-Combating a Timeless Silent Killer, 37 RUTGERS L. REC. 300, 301.

146. Centers for Disease Control and Prevention, Preventing Lead POISONING IN CHILDREN 2-3 (2005), available at http://www.cdc.gov/nceh/ lead/publications/prevlead poisoning.pdf.

147. See generally California Department of Community Services and Development, Lead-Based Paint Hazard Control Program, http://www.csd.ca. gov/Programs/Lead-Based\%20Paint\%20Hazard\%20Control\%20Program.aspx (last visited Jan. 28, 2012) (on file with Washington and Lee Law Review).

148. See Kenneth Lepage, Lead-Based Paint Litigation and the Problem of Causation: Toward a Unified Theory of Market Share Liability, 37 B.C. L. REV. 155,158 (1995) ("Due to the generic nature of the effects of lead poisoning, it can be difficult to show both that lead poisoning is the cause of specific health 
behavioral problems can be caused by a wide range of factors, many of which are frequently present simultaneously for any particular child who has an elevated BLL.149 Epidemiological data strongly supports the association between exposure to lead paint and increased prevalence of low IQ and behavioral problems at the population level. But it can be extremely difficult to establish causation with respect to any particular individual.

Public nuisance litigation offered a potential alternative to suits based on individual harms, but its success has been limited. The public nuisance claims were based on the theory that the presence of lead pigment in homes and other buildings constitutes an unreasonable interference with public health and safety and that the defendant manufacturers and distributors contributed to this nuisance. The Rhode Island Attorney General achieved a highly publicized victory in the form of a jury verdict that was upheld by the state trial court. ${ }^{150}$ But the verdict was later overturned by the Rhode Island Supreme Court and courts in other jurisdictions rejected similar claims. ${ }^{151}$ The lead paint plaintiffs had a more difficult time than the firearms plaintiffs in framing the nuisance at issue as associated with the defendants' affirmative conduct rather than the product itself. For example, the New Jersey Supreme Court characterized the defendants' conduct as "merely offering an everyday household product for sale."152 This framing of the nuisance at issue as the product itself left the claims susceptible to dismissal on the grounds that the defendants lacked control over the nuisance at the time that it

defects and that a specific case of lead poisoning is due to lead paint." (footnote omitted)); Brenner v. Am. Cyanamid Co., 699 N.Y.S.2d 848, 853 (N.Y. App. Div. 1999) (stating that "there is no signature injury associated with lead poisoning").

149. See Richard L. Canfield et al., Intellectual Impairment in Children with Blood Lead Concentrations Below $10 \mathrm{~g}$ per Deciliter, 348 NEW ENG. J. MED. 1517, 1519 (2003) (listing covariables used which were based on established predictors of children's intellectual outcomes).

150. Rhode Island v. Lead Indus. Ass'n, No. PC 99-5226, 2007 WL 711824 (R.I. Super. Ct. Feb. 26, 2007).

151. Rhode Island v. Lead Indus. Ass'n, 951 A.2d 428 (R.I. 2008); see also Faulk \& Gray, supra note 113, at 978-79, 1007-14 (describing the failure of suits in Wisconsin and New Jersey).

152. In re Lead Paint Litig., 924 A.2d 484, 501 (N.J. 2007). 
caused harm. ${ }^{153}$ To the extent that the nuisance is understood to be the product itself, manufacturers cannot be said to control it after it is sold to consumers. Nonetheless, despite an overall trend toward rejection of industry-wide public nuisance liability, as recently as June 2011, several California municipalities reached an $\$ 8.7$ million settlement in a suit against the lead paint industry. ${ }^{154}$

Industry-wide public nuisance claims also received a temporary boost from the decision of the Second Circuit to allow a public nuisance suit to proceed against the coal-fired power plant industry based on the harms associated with climate change. ${ }^{155}$ The decision was ultimately overturned, however, by the Supreme Court in June 2011 in American Electric Power Co., Inc. $v$. Connecticut. ${ }^{156}$ Climate change public nuisance litigation has been split between more typical environmental nuisance

153. Id. at 499; Lead Indus. Ass'n, 951 A.2d at 455 (overturning jury verdict and trial court order because plaintiffs had failed to establish that the manufacturers interfered with a public right or that they were in control of the lead pigment at the time that it caused harm to Rhode Island children). Courts dismissing firearms public nuisance claims relied on similar arguments. See, e.g., Hamilton v. Beretta U.S.A. Corp., 750 N.E.2d 1055, 1061-62 (N.Y. 2001) (finding no duty because gun manufacturers did not control criminals with guns, and injuries were too remote); Camden Cnty. Bd. v. Beretta U.S.A. Corp., 273 F.3d 536, 541 (finding the causal chain between manufacture of handguns and municipal crime-fighting costs too attenuated to attribute sufficient control to manufacturers to make out a public nuisance claim); City of Philadelphia v. Beretta U.S.A. Corp., 277 F.3d 415 (3d Cir. 2002) (stating that even though illegal use of firearms may constitute a public nuisance, defendant was not liable because the firearms were no longer under its control).

154. Millennium Holdings Settles Lead Paint Cases for $\$ 8.7$ Million, LITIGATION BLOG, http://www.lexisnexis.com/community/litigationresourcecenter /blogs/litigationblog/archive/2011/06/24/millennium-holdings-to-pay-8-7-million-tosettle-lead-paint-claims.aspx (last visited Jan. 28, 2012) (on file with Washington and Lee Law Review). This victory does not necessarily indicate the long-term viability of industry-wide public nuisance claims, given that California courts have given a particularly expansive interpretation to public nuisance doctrine. See Matthew R. Watson, Comment, Venturing into the "Impenetrable Jungle": How California's Expansive Public Nuisance Doctrine May Result in an Unprecedented Judgment Against the Lead Paint Industry in the Case of County of Santa Clara v. Atlantic Richfield Company, 15 Roger WiLliams U. L. REV. 612,614 (2010).

155. Connecticut v. Am. Elec. Power Co., 582 F.3d 309, 367 (2d Cir. 2009) (alleging that emissions from smokestacks of coal-fired power plants contributed to the public nuisance of climate change).

156. Am. Elec. Power Co., Inc. v. Connecticut, 131 S. Ct. 2527 (2011). 
litigation based on emissions from the defendants' property and innovative industry-wide nuisance litigation based on greenhouse gas emissions from defendants' products. The suit that was eventually rejected by the U.S. Supreme Court after being allowed to proceed by the Second Circuit was a more traditional property-based environmental nuisance case. ${ }^{157}$ The defendants were operators of coal-fired power plants that emit greenhouse gases from their properties. A suit that was withdrawn by the plaintiffs in 2009 after an adverse federal district court ruling was more akin to the suits against the lead paint and firearms industries. The defendants in California $v$. General Motors Corp. ${ }^{158}$ were automobile manufacturers and the public nuisance claim was based on the contribution of the defendants' products to climate change via their emissions after they were sold and used by consumers. ${ }^{159}$

\section{The Scope of Public Rights in Public Nuisance Law}

The uniquely public nature of public nuisance is in danger of being lost amid the current backlash against the cause of action. A handful of tort law scholars-including Donald Gifford, ${ }^{160}$ Victor Schwartz, and Phil Goldberg161_have articulated a scathing (and influential) critique of what they view as a proposed expansion of public nuisance liability. They have argued that public nuisance claims against products manufacturers should be dismissed because they can only be brought under products liability law. Several courts have reached the same

157. Connecticut, 582 F.3d at 367 (alleging that emissions from smokestacks of coal-fired power plants contributed to the public nuisance of climate change).

158. California v. Gen. Motors Corp., No. C06-05755, 2007 WL 2726871 (N.D. Cal. Sept. 17, 2007).

159. Id. (alleging that emissions from the defendants productsautomobiles-contributed to the public nuisance of climate change).

160. See generally Donald G. Gifford, Public Nuisance as a Mass Products Liability Tort, 71 U. CIN. L. REv. 741 (2003) [hereinafter Gifford, Public Nuisance]; GIFFORD, supra note 99; Donald G. Gifford, Climate Change and the Public Law Model of Torts: Reinvigorating Judicial Restraint Doctrines, 62 S.C. L. REv. 201 (2011) [hereinafter Gifford, Climate Change].

161. Schwartz \& Goldberg, supra note 114, at 552. 
conclusion, ${ }^{162}$ effectively rejecting the non-property based, "public rights" version of the public nuisance tort. Public nuisance advocates have disagreed sharply with this view, arguing that products liability is simply not the proper framework for understanding the harm that these suits have attempted to address. ${ }^{163}$ They have viewed public nuisance claims as a means of addressing the underlying causes of social ills, not as a means of marginally increasing the safety of particular products. ${ }^{164}$

Courts sense (rightly, I think) that they must be cautious about when plaintiffs are allowed to take advantage of the flexible fault and causation doctrines associated with public nuisance. ${ }^{165}$ They have been anxious to dismiss industry-wide public nuisance claims, but their opinions taken as a whole fail to articulate a consistent, principled basis for doing so. In many cases, courts have applied more stringent doctrines of fault and causation from personal injury law to public nuisance claims, ${ }^{166}$ effectively watering down the power of public nuisance by making it less different from personal injury analysis. Public nuisance advocates have attempted to clarify the principled distinctions between public nuisance claims arising out of public harms and

162. See, e.g., City of Chicago v. Am. Cyanamid Co., 823 N.E.2d 126, 135 (Ill. App. Ct. 2005) (finding persuasive defendants' argument "that plaintiff cannot escape the requirement of showing causation in fact by stylizing a products liability claim as a public nuisance action").

163. See, e.g., Kairys, Origin and Development, supra note 128, at 1172 ("[P]reliminary research showed that product liability, I thought, was problematic because handguns aren't defective. That's not the problem; they work quite well-too well, by my light.").

164. See Developments, supra note 118, at 1758-59 (describing municipal suits against tobacco firms and handgun manufacturers as novel forms of collectivization: "[S] uch litigation takes advantage of the civil law's flexibility to respond to newly recognized problems and exploits its substantive reach to go beyond the crimes at issue to address their alleged underlying causes"). Public nuisance suits differ from class action suits, however, in that class action suits are fundamentally premised on the aggregation of individual claims, whereas public nuisance suits are premised on a collective harm.

165. See generally Jules Coleman \& Arthur Ripstein, Mischief and Misfortune, 41 McGiLL L.J. 91 (1995).

166. See generally Abrams \& Washington, supra note 115; Steven Sarno, In Search of a Cause: Addressing the Confusion in Proving Causation of a Public Nuisance, 26 PACE ENVTL. L. REV. 225 (2009). See also People ex rel. Spitzer v. Sturm, Ruger \& Co., 761 N.Y.S.2d 192, 207 (App. Div. 2003) (Rosenburger, J., dissenting) (arguing that the majority opinion "appl[ies] an inapposite negligence analysis to this case"). 
private claims arising out of similar harms to individuals. ${ }^{167} \mathrm{But}$ many courts have remained unpersuaded. ${ }^{168}$ The result is that most courts have dismissed industry-wide public nuisance claims without determining how best to define "public rights" as a means of delineating the boundary between a properly alleged public nuisance and other kinds of tort claims. ${ }^{169}$

The public right element has been described as "the sine qua non of a cause of action for public nuisance." 170 It is grounded in the same community-focused theory that animated the foundation of American public health law. In his 1893 treatise on the law of nuisance, H.G. Wood referred to public nuisance as "a part of the great social compact to which every person is a party, a fundamental and essential principle in every civilized community, that every person yields a portion of his right of absolute dominion."171 In the 1990s, the California Supreme Court similarly defined public nuisance as an "interference with collective social interests," noting that it is this "community aspect of the public nuisance... that distinguishes it from its private cousin, and makes possible its use, by means of the

167. See, e.g., Am. Cyanamid Co., 823 N.E.2d at 134

Plaintiff asserts that because it is a governmental plaintiff it is not required to identify which defendant manufactured the paint found on each surface in Chicago where lead-based paint now constitutes a hazard. ... Plaintiff notes that, in the present case, it is not seeking to recover for an injury to a particular person or property but, instead, it is asserting the right of the public as a whole to be free from threats to its health and safety.

168. See id. (rejecting the plaintiff's causation analysis and, in doing so, falling back on requiring a tie to property via the causation requirement). "[T]here is no reported Illinois public nuisance case involving a viable lawsuit brought by any municipality in which identification and causation, including the specific location of the nuisance, were not known." Id.

169. See, e.g., City of Chicago v. Beretta U.S.A. Corp., 821 N.E.2d 1099, 1113 (Ill. 2005) (noting that although the majority of public nuisance firearms suits had been dismissed on some grounds, no court had dismissed a public nuisance suit against firearms manufacturers and distributors on the basis of "failure to properly plead the existence of a public right affected by the alleged nuisance").

170. 58 AM. JUR. 2D Nuisances $\S 39$ (2002) (quoted in City of Chicago, 821 N.E.2d at 1115); see also City of Chicago, 821 N.E.2d at 1113-14 ("[T] he first element that must be alleged to state a claim for public nuisance is the existence of a right common to the general public.").

171. H. WoOd, a Practical Treatise on the LaW of Nuisances in Their VARIOUS FORMS; INCLUDING REMEDIES THEREFORE AT LAW AND IN EQUITY $§ 1$ (3d ed. 1893). 
equitable injunction, to protect the quality of organized social life." 172 The court drew on the long history of nuisance doctrine, noting that "[t]he public nuisance doctrine ... embodies a kind of collective ideal of civil life which the courts have vindicated by equitable remedies since the beginning of the 16th century." 173

Despite wide agreement that interference with a public right is the central element of a public nuisance, ${ }^{174}$ courts and commentators have struggled in their attempts to use the public right element as a means for defining the substantive scope of the cause of action. The Restatement's broad formulation of a public nuisance as involving "a significant interference with the public health, the public safety, the public peace, the public comfort or the public convenience" 175 has been widely quoted, but rarely dispositive. ${ }^{176}$ The criteria set forth in the second edition of American Jurisprudence are only slightly more instructive. A public nuisance "must affect an interest common to the general public, must produce a common injury, or be dangerous or injurious to the general public, or it must be harmful to the public health, or prevent the public from a peaceful use of their land and the public streets, or there must be some direct encroachment on public property." 177

In the context of recent litigation against the firearms and lead paint industries, courts that have considered the application of the public right requirement in detail have been split as to whether public rights are implicated. Courts allowing public nuisance claims to proceed have typically framed the public right

172. People ex rel. Gallo v. Acuna, 929 P.2d 596, 604 (Cal. 1997).

173. Id. at 603 (enjoining street gang members from conducting violent and intimidating activities in a San Jose neighborhood).

174. See, e.g., Young v. Bryco Arms, 765 N.E.2d 1, 10 (Ill. App. Ct. 2001) ("The first element that a plaintiff must allege in order to state a claim for public nuisance is the existence of 'a right common to the general public.").

175. RESTATEMENT (SECOND) OF TORTS § 821B (1979).

176. For the rare exception, see, for example, Ileto v. Glock, Inc., 349 F.3d 1191, 1209-10 (9th Cir. 2003) (noting that California had adopted the Restatement's five categories of public rights, [public health, safety, peace, comfort, or convenience] and then parroting without discussion the plaintiffs' complaint that the plaintiffs' gunshot injuries were violations of their public rights to "health, safety, and welfare").

177. 58 AM. JUR. 2D Nuisances $\S 39$ (2002) (quoted in City of Chicago v. Beretta U.S.A. Corp., 821 N.E.2d 1099, 1115 (Ill. 2005)). 
at issue in broad terms that echo those of the Restatement. In Young v. Bryco Arms (a firearms case), for example, an Illinois court was swayed by the plaintiffs' fairly broad assertion that "the rights of plaintiffs and others to use the streets and public ways without fear, apprehension and injury"178 amounted to a public right, but the same court renounced similar reasoning in a subsequent case. ${ }^{179}$ Similarly, in Lewis $v$. Lead Industries Ass'n (a lead paint case), another Illinois court noted that "[t]he public health and safety are common rights an interference with which is sufficient to support a public nuisance claim." ${ }^{180}$ For the most part, however, courts that have explicitly considered the public right element have rejected such broad assertions. In a firearms case, the Illinois Supreme Court rejected a public right to be "free from unreasonable jeopardy to health, welfare, and safety, and from unreasonable threats of danger to person and property, caused by the presence of illegal weapons in the city of Chicago."181 Similarly, in overturning the jury verdict for the plaintiffs in the Rhode Island lead paint case, the state Supreme Court rejected the public right "to be free from the hazards of unabated lead," noting that "this contention falls far short of alleging an interference with a public right as traditionally has been understood in the law of public nuisance. The state's allegation that defendants have interfered with the 'health, safety, peace, comfort or convenience of the residents of the [s] tate'... standing alone does not constitute an allegation of interference with a public right."182 This argument ignores nearuniversal adoption of the Restatement's formulation of public health as firmly entrenched within the scope of public rights. It also disregards the role of state and local government officials

178. Bryco Arms, 765 N.E.2d at 11 (citation and internal quotation marks omitted). Other courts have held, however, that the concept of unreasonable interference with public rights does not include the sale and distribution of handguns that pose a threat to public safety. See, e.g., City of Philadelphia v. Beretta U.S.A. Corp., 277 F.3d 415, 421-22 (3d Cir. 2002); Camden Cnty. Bd. of Chosen Freeholders v. Beretta U.S.A. Corp., 273 F.3d 536, 541-42 (3d Cir. 2001).

179. See infra note 206.

180. Lewis v. Lead Indus. Ass'n, 793 N.E.2d 869, 878 (Ill. App. Ct. 2003).

181. City of Chicago v. Beretta U.S.A. Corp., 821 N.E.2d 1099, 1114 (Ill. 2005).

182. State v. Lead Indus. Ass'n, 951 A.2d 428, 453 (R.I. 2008). 
suing in their parens patriae role, which has long been understood to encompass public health protection.

\section{Theorizing the Public in Public Health and Public Nuisance}

Although the theoretical debate over new public health law and the doctrinal debate over industry-wide public nuisance litigation have each generated substantial scholarly commentary, no one has noted the parallels between them. ${ }^{183}$ In both contexts, as described above, designating a concern as "public" alters the way in which it is balanced against protections for individual rights and interests. To borrow William Novak's formulation, the public label designates "a special sphere of social activity, a sphere distinctly cognizable as an object of governance."184 Both debates have been triggered by advocates' efforts to reach beyond the immediate causes of modern social problems to address their underlying roots. In doing so, advocates have attempted to make use of venerable legal tools for addressing public problems. In response to perceived overreaching, critics of a broader scope for public health and public rights have argued for a more circumscribed understanding of the "public."

The linkages between industry-wide public nuisance litigation and the new public health law movement are evident in the writings of David Kairys, a legal scholar who played a significant role in developing the public nuisance strategy against the firearms industry. ${ }^{185}$ Kairys's account suggests that the

183. Although Epstein has written separately about public nuisance law, see Richard A. Epstein, Federal Preemption, and Federal Common Law, in Nuisance Cases, 102 Nw. U. L. REV. 551, 559-60 (2008) (discussing property-based public nuisance claims), he has not explicitly connected his two critiques. He specifically includes "public nuisances like widespread pollution" as among the proper objects of "old" public health law. But in his work on the scope of public health law, he has not referred to public nuisance litigation against product manufacturers. Epstein, In Defense of the "Old" Public Health, supra note 83, at 1425. In arguing that the "new" public health approach "extends regulation into inappropriate areas," Epstein does, however, refer specifically to the regulation of product markets. Id.

184. NovAK, supra note 31 , at 86.

185. Kairys, Origin and Development, supra note 128 , at 1163 . The public nuisance litigation strategy was first developed in Philadelphia, but the mayor of Philadelphia eventually backed away from filing suit and chose instead to collaborate with the National Rifle Association to lobby for additional federal 
strategy arose out of exactly the sort of "root cause" analysis that the ecological model of public health has sought to promote. Kairys explains that in 1996, he was asked to serve alongside police officers, prosecutors, and community activists on a gun violence taskforce for the city of Philadelphia. The group also included police officers, prosecutors, and community and religious activists. They sought to address gun violence, not as a "regrettably normal phenomenon in our society," but rather as an "intolerable, unacceptable" problem that they sought to "figure out." 186 Ultimately, the taskforce traced gun violence to an environment in which guns are readily available on the black market, thanks to the distribution practices of gun manufacturers and their wholesale distributors. ${ }^{187}$

The distinction between the product liability strategy and the public nuisance strategy maps nicely onto the contrasting models of public health described above. Products liability claims aimed at altering the design of particular firearms, for example, are more in line with an agent model of gun violence. If the gun is the agent that causes injury, then the solution is to alter the gun itself. The individually-oriented causation analysis applied to products liability also maps onto the agent model of public health by focusing on establishing clear ties between specific causes and specific outcomes. On the other hand, public nuisance claims against the firearms industry as a whole to address marketing and distribution practices that influence where guns are located is more in keeping with an ecological model. The public nuisance suits put forward understanding of harmful products like firearms as posing "an environmental threat as well as [being] the object of a series of commercial transactions that caused a clustering of individual illnesses through product exposure."188

Kairys, in his role as public nuisance advocate, explicitly turned to the terminology of public health to describe the firearms market:

funds for law enforcement. The strategy was quickly picked up by other city and state governments, however. See Carl T. Bogus, Gun Litigation and Societal Values, 32 ConN. L. REv. 1353, 1353-56 (2000).

186. Kairys, Origin and Development, supra note 128, at 1164.

187. Id. at 1173.

188. GIFFORD, supra note 99 , at 84 (emphasis added). 
What was clear to me was that the... moving force for demand in this industry is fear. You can think of it as an epidemic, as the public health people might think of it, but it's an epidemic that's spread not by a virus or a bacteria. It's an epidemic that's spread by fear. And unlike most epidemics, the cause is also posed as the solution. The solution-more gunsjust further spreads the epidemic. ${ }^{189}$

This use of the term "epidemic" with respect to noncommunicable threats to health has been decried by Epstein as fostering a predisposition toward government intrusion as an appropriate response. ${ }^{190}$ For Epstein, modern public health epidemics like obesity and diabetes are not "epidemics" at all. Indeed, Epstein points to the epidemic label as having implications similar to those of the public label: "There are no non-communicable epidemics.... [T] he designation of obesity as a public health epidemic is designed to signal that state coercion is appropriate, and it is just that connection that is missing." 191 Writing about the scope of public health law, Hall cautions that the public health perspective tends toward a "habit of thought" whereby "having identified a causal connection to a widespread health problem, action is necessary to eradicate the cause and eliminate the problem at its source, and it falls within the authority of public health or other government officials to take the necessary actions." He could just as easily have been describing David Kairys's story about the gun violence task force.

The efforts of public health and public nuisance critics to theorize a narrower vision of the public have proceeded from the presumption that it must be more than the mere aggregation of individual interests, rights, or harms. Efforts to define what this "something more" might be have thus far proceeded along two main paths. Some have turned to theoretically specious means for designating a private sphere in which harms cannot be conceived of as "public." Others have turned to the conception of indivisible public goods. Both conceptions lead to relatively narrow grounds of justification for restraints on liberty, even in the hands of proponents of a broader understanding of public health. ${ }^{192}$

189. Kairys, Origin and Development, supra note 128, at 1167-68.

190. Epstein, supra note 11, at S154.

191. Id.

192. See Bruce Jennings, Public Health and Liberty: Beyond the Millian 


\section{A. Aggregation Is Insufficient}

Hall has described the "key insight" of his critique of public health law as follows: "in the legal arena, public has a specialized meaning that is quite different from ordinary parlance. In the legal arena, public does not simply mean 'widespread."'193 Pope puts a similar insight in terms of identifying an appropriate liberty limiting principle for public health interventions. He notes the argument by Mary Ann Glendon and others that many behaviors that are seemingly purely self-regarding behaviors (those posing no risk of harm to others and thus properly conceived of as "private") in fact impose economic costs on society in the form of medical expenses and lost productivity. But Pope disputes this as a justification for government intrusion: "[W] hile there may be cases in which aggregate de minimus self-regarding harm becomes collective harm, more is needed before the mere invocation of 'the community' justifies limiting liberty."194

Ironically, Dan Beauchamp, a pioneer in theorizing the ethical foundations of the ecological model of public health, ${ }^{195}$ expressed a similar sentiment in championing a broad conception of public health. And he did so decades before Hall and Epstein offered the same notion as a critique.

The public or the people were presumed to have an interest, held in common, in self-protection or preservation from threats of all kinds to their welfare.... The central principles underlying the police or regulatory power were the treatment of health and safety as a shared purpose and need of the community and (aside from basic constitutional rights such as due process) the subordination of the market, property, and

Paradigm, Pub. Health ETHICs 2, no. 2, 131 (2009) ("[P]ublic health ethics must go beyond the Millian paradigm and its individualism."). The author also notes that "the normative justification for public health practice outside a very narrow range" cannot be sustained. $I d$. at 130 .

193. Hall, supra note 65, at S204.

194. Pope, supra note 9 , at 32 .

195. See, e.g., Dan E. Beauchamp, Public Health As Social Justice, in New ETHICS FOR THE PUBlic's HEalTh 101, 101 (Dan E. Beauchamp \& Bonnie Steinbock eds., 1999) (article originally appeared in 1976) ("[O]ur most intractable public problems... result in significant part from arrangements that are providing substantial benefits or advantages to a majority or to a powerful minority of citizens.... It is not sufficiently appreciated that these same bleak realities plague attempts to protect the public's health."). 
individual liberty to protect compelling community interests. ... In this scheme, public health and safety are not simply the aggregate of each private individual's interest in health and safety, interests which can be pursued more effectively through collective action. ${ }^{196}$

Notably for my purposes, Beauchamp's statement could just as easily have been written in reference to the definition of public rights in public nuisance law.

This rejection of the public as merely "widespread" has been equally crucial in courts' and commentators' rejection of the existence of a public right in the firearms and lead paint litigation. Courts have expressed the idea that aggregated private harms are not grounds for a public rights public nuisance claim. For example, in City of Chicago v. Beretta U.S.A. Corp., the court "quer[ied] whether the public right asserted by plaintiffs is merely an assertion, on behalf of the entire community, of the individual right not to be assaulted."197 Similarly, the New Jersey Supreme Court, in In re Lead Paint Litigation, expressed skepticism as to "whether the condition addressed [lead paint exposure] truly affects a common right rather than merely affecting many people." 198 In overturning a jury verdict holding lead paint manufacturers liable for contributing to a public nuisance, the Rhode Island Supreme Court noted that the meaning of public right could not be so broad as "to encompass all behavior that causes a widespread interference with the private rights of numerous individuals." 199

The collective-individual distinction is referenced in a comment to the Restatement, which cautions that a public right "is collective in nature and not like the individual right that everyone has not to be assaulted or defamed or defrauded or negligently injured." Donald Gifford and others have built on this

196. Dan Beauchamp, Community: The Neglected Tradition of Public Health, 15 HASTINGS CTR. REP. 28, 29 (1985) (emphasis added).

197. City of Chicago v. Beretta U.S.A. Corp., 821 N.E.2d 1099, 1115 (Ill. 2005) (holding defendants' marketing of firearms did not constitute a public nuisance in Illinois).

198. In re Lead Paint Litig., 924 A.2d 484, 501 (N.J. 2007). Ultimately, however, the court deferred to the legislature's interpretation of a broader meaning of "common right" that would encompass a public nuisance created by lead paint and dismissed the claim on other grounds. Id.

199. Rhode Island v. Lead Indus. Ass'n, 951 A.2d 428, 453 (2008). 
distinction to argue that conduct that harms a large number of people does not necessarily interfere with a public right. In many cases, widespread harms are better understood as a simple aggregation of individual harms without any special significance for communal interests. Gifford uses the example of contaminated hamburgers to illustrate the point:

Even if the owners of a fast-food chain were to sell millions of defectively produced hamburgers causing harm to millions of people who ate them, the violation of rights is a series of separate violations of private rights-typical tort or contract rights that the consumers might have-not a violation of the rights of the general public, or of the public as the public. The sheer number of violations does not transform the harm from individual injury to communal injury. ${ }^{200}$

The critics of new public health would likely take issue with Gifford's characterization of contaminated meat as not within the legitimate corpus of distinctly public harms. They have typically included actions to ensure the safety of the food supply as among the legitimate functions of "old" public health. ${ }^{201}$ The devil, it seems, is in the details-if the "public" requires something more than simple aggregation, then how should that "something more" be defined and theorized?

\section{B. Public Spaces}

Gifford's conception of the public appears to rely on a notion that at least some problems cannot properly be deemed public simply by virtue of their originating in private places at the hands of private actors. In 2003, Gifford wrote that "[p]roducts generally are purchased and used by individual consumers. Any harm they cause-even if the use of the product is widespread and the manufacturer's or distributor's conduct is unreasonable-

200. GIFFORD, supra note 99, at 146; see also In re Lead Paint Litig., 924 A.2d at 501. In re Lead Paint Litig. expressed skepticism as to whether lead paint poisoning "truly affects a common right rather than merely affecting many people," but ultimately deferred to the legislature's interpretation of a broader meaning of "common right" that would encompass a public nuisance created by lead paint. Id.

201. See Hall, supra note 65, at S204. 
is not an actionable violation of a public right."202 For Gifford, there is nothing public about contaminated hamburgers consumed in privately owned establishments by individual consumers. His commentary has been particularly influential in the lead paint cases. In critiquing the lead paint public nuisance claims, Gifford argues that "[t]he concept of public right as that term has been understood in the law of public nuisance does not appear to be broad enough to encompass the right of a child who is lead-poisoned as a result of exposure to deteriorated lead-based paint in private residences or child-care facilities operated by private owners." 203 His reasoning is baffling to anyone familiar with the critical deconstruction of the public-private distinction: "Despite the tragic nature of the child's illness, the exposure to lead-based paint usually occurs within the most private and intimate of surroundings, his or her own home."204 Feminist scholars and others have harshly and thoroughly critiqued the carving out of the home as a private sphere in which the public interest should have no influence. ${ }^{205}$ Nonetheless, Gifford's reasoning is apparently appealing to courts, at least two of which have quoted the above language in dismissing lead paint nuisance claims. ${ }^{206}$

202. GIFFORD, supra note 99, at 146.

203. Id. at 147 .

204. Id.; see also Faulk \& Gray, supra note 113, at 983-84 ("[T] he alleged problems did not threaten the exercise of any rights held by the public at large, such as the use of public buildings or resources, but rather related to the exercise of private rights by private individuals in their private abodes.").

205. See Ruth Gavison, Feminism and the Public/Private Distinction, 45 STAN. L. REV. 1, 13-14 (1992).

206. So influential, in fact, that the same Illinois Appeals Court that had accepted a broad reading of public rights in an earlier case, Lewis $U$. Lead Industries Ass'n, Inc. 793 N.E.2d 869 (Ill. App. Ct. 2003), was so swayed by Gifford's reasoning and the defense arguments inspired by it, that it renounced Lewis's conclusion in a subsequent case. See City of Chicago v. Am. Cyanamid Co., 823 N.E.2d 126, 132-33 (IIl. App. Ct. 2005). The court quoted Gifford and noted:

[P]laintiff alleges that the nuisance, if one exists, occurs in unidentified buildings owned by private property owners. Defendants argue that plaintiff's allegations implicate an assortment of claimed private individual rights that do not belong to the public at large because the alleged conditions exist within private homes, which the general public has no right to enter, and therefore do not interfere with any "public right." 
Gifford applies similar reasoning to tobacco litigation. He rejects the argument that public nuisance liability could attach to harms experienced by primary smokers, but he draws a distinction when it comes to harms associated with secondhand smoke, on quite unconventional grounds: "Conceivably, a victim of tobacco related-illness who could prove that her disease resulted from 'second-hand' smoke, particularly in public places such as public parks or while walking on public thoroughfares, could satisfy this first requirement of public nuisance." 207 The typical distinction between being the primary smoker and being exposed to secondhand smoke is that self-protection (choosing not to smoke) is not possible for the person exposed to secondhand smoke. Gifford's emphasis on the notion that harms associated with secondhand smoke are particularly actionable through public nuisance where the exposure occurs in "public parks" or "public thoroughfares" offers a novel spin on that distinction. Gifford's focus on public spaces may also provide some explanation for his acceptance of the public right argument with respect to the firearms litigation. ${ }^{208}$ Perhaps Gifford is swayed by the framing of the public right violation in the firearms litigation as interference with the public's "peaceful use of public streets, sidewalks, parks, and other public places." 209 In any case, this place-based view of the public-private distinction has not taken hold among the liberal critics of new public health. Even Epstein agrees that environmental pollution and contamination of the food supply are legitimate concerns of his favored "old" public health. ${ }^{210}$ Presumably this holds for Epstein even when these

Id. at 132. Somewhat confusingly, the court also acknowledged, however, that "[a] public nuisance is actionable even where the nuisance is present on private property." Id. at 133 . Ultimately, the court avoided the issue by dismissing the case on proximate cause grounds. Id.; see also In re Lead Paint Litig., 924 A.2d at 495 .

207. Gifford, Public Nuisance, supra note 160, at 817.

208. Id.

209. City of New York v. A-1 Jewelry \& Pawn, Inc., 247 F.R.D. 296, 349 (E.D.N.Y 2007) (holding the City of New York had sufficiently pled a public nuisance claim against out-of-state firearm retailers).

210. See, e.g., Richard A. Epstein, The Principles of Environmental Protection: The Case of Superfund, 2 CATo J. 9, 33-34 (1982) (suggesting that "government... be given broad and immediate powers to clean up and regulate existing [environmentally hazardous dumps or spills]" because "they present the greatest threats of large-scale pollution and the greatest obstacles 
threats are experienced by people within private homes or as a result of purchases from private businesses.

\section{Public Goods}

A more theoretically sound basis for the public-private distinction is offered by Epstein and Hall, who have emphasized the indivisible nature of public goods (such as clean air or herd immunity) in defining what it is that sets the truly public apart from the aggregation of private concerns. Epstein, not unexpectedly, defines the difference between "old" public health and new public health in economic terms:

For its part, the old public health tracks the idea of public goods in economics, namely, those non-excludable goods that cannot be supplied to one unless they are also given to another.... It thus invokes an analogous concept for "public bads": those harms inflicted on others without their consent, as, for example, both communicable diseases and pollution. ${ }^{211}$

By contrast, in Epstein's view, modern public health has become "unmoored from the economic conception of a (non-excludable) public good."212 Similarly, Hall has argued that "[i]n the legal arena, public... invokes a special set of justifications for government intervention and coercion that rely on concepts that economists refer to as "public goods."'213 Proponents of public health intervention have also described public health in terms of protecting public goods. Michael Walzer, for example, defined public health law as "focus[ing] on the provision and protection of public goods, without specific allocation to individuals. ${ }^{214}$

to private relief"); Richard A. Epstein, Eggs and Avastin, Forbes (Aug. 23, 2010, 11:34 AM), http://www.forbes.com/2010/08/23/fda-eggs-salmonellaopinions-columnists-richard-a-epstein.html (last visited Jan. 28, 2012) (arguing that the FDA should refocus its efforts and resources towards traditional public health concerns such as preventing contamination in the food supply) (on file with the Washington and Lee Law Review).

211. Epstein, supra note 11, at S139.

212. Id. at $\mathrm{S} 148$.

213. Hall, supra note 65, at S204. Hall goes on to discuss how public health officials, overstepping this public good distinction, might "use their vast legal authority to try to solve problems that are not collective action problems" and terms this behavior "the public fallacy." Id. at S205.

214. Michael Walzer, Spheres of Justice: A Defense of Pluralism and 
Similarly, James Childress and Ruth Gaare Bernheim have written that "[ $t]$ he health of the public is a public good because it is not just the sum of individual health indices and cannot be attained through individual actions alone."215 For Hall and Epstein, however, the public goods criteria amounts to a narrow justification for "old" public health measures to address communicable infectious disease threats, pollution of the natural environment, and contaminated food. ${ }^{216}$

A parallel argument has been made with respect to public nuisance law. Modern courts and commentators have read early cases as limiting the recognition of public rights to "those indivisible resources shared by the public at large, such as air, water, or public rights of way." 217 This conception of public rights

EQUALITY 2 (1983).

215. James F. Childress \& Ruth Gaare Bernheim, Beyond the Liberal and Communitarian Impasse: A Framework and Vision for Public Health, 55 FLA. L. REV. 1191, 1195 (2003).

\section{See Hall, supra note 65 , at S204}

The classic subjects of public health law are communicable diseases, personal hygiene, sanitary water and sewer systems, safe food, and injury prevention. These disparate situations all involve significant collective action problems, meaning that individuals acting in their own self-interest, even if fully informed and rational, will not effectively address the problem because they do not internalize some of the major costs or benefits of action or non-action, or for other reasons a centralized response is much more cost-effective... Identifying and eliminating the source of contagion for a communicable disease requires more effort and cost than any one individual or small group is likely to undertake. A public agency is necessary to garner the resources needed for collective action and to wield the authority for coercive restrictions on liberty or property.

217. State v. Lead Indus. Ass'n, 951 A.2d 428, 454 (R.I. 2008) ("The term public right is reserved more appropriately for those indivisible resources shared by the public at large, such as air, water, or public rights of way.") (citing City of Chicago v. Am. Cyanamid Co., 823 N.E.2d 126, 131, 139 (Ill. App. Ct. 2005)); see also Graham Oil Co. v. BP Oil Co., 885 F. Supp. 716, 723 (W.D. Penn. 1994) (including the rights to soil and water free of contamination as public rights); City of Philadelphia v. Beretta U.S.A. Corp., 126 F. Supp. 2d 882, 90809 (E.D. Pa. 2000) (comparing plaintiffs' assertion of a public "right to be free from guns and violence" to a public right to unpolluted water and then rejecting the plaintiffs' argument), affd, 277 F.3d 415 (3d Cir. 2002); Philadelphia Elec. Co. v. Hercules, Inc., 762 F.2d 303, 316 (3d Cir. 1985) (finding the right to pure water is a public right); Celanese Corp. v. Coastal Water Auth., 475 F. Supp. 2d 623, 639 (S.D. Tex. 2007) (listing the enjoyment of clean air and water as examples of public rights); Gifford, Public Nuisance, supra note 160 , at 793 (noting that "the obstruction of highways or diversion of watercourses" are 
as public goods first emerged from the application of public nuisance to environmental pollution. It harkens back to nuisance cases that recognized rights to clean air and water and safe and unobstructed use of public rights of way, but it fails to reach back to the earlier conception of collectively held rights to public health and welfare out of which those more specific environmental rights arose. The application of public nuisance to problems like lead paint in homes and the illegal firearms market put pressure on the public goods formulation. As described above, advocates and courts have increasingly eschewed broad statements of a right to public health and welfare in favor of narrower (and increasingly awkward) assertions of rights to specific public goods stated in affirmative terms. Recently asserted public goods include "a climate that will not drastically change as a result of greenhouse gas 'pollution,' thereby devastating the ecology and the human population" 218 and "the benefits of the laws governing the unlawful possession and use of firearms." 219 When the interests at issue are framed so narrowly, it's not difficult to see why courts have been quick to dismiss the argument that they are protected by longstanding common law rights.

\section{Epidemiological Harms as Public Bads}

The implementation of measures that integrate new public health science and practice into public health law and policy is proceeding rapidly. Measures aimed at altering the social environment in ways that influence health behaviors and outcomes are supported by public health science, ${ }^{220}$ but they are perhaps rushing ahead of adequate theorization in terms of values other than population health. For the most part, the defense of new public

classic public nuisances).

218. Connecticut v. Am. Elec. Power Co., 582 F.3d 309, 367 (2d Cir. 2009), rev'd, 131 S. Ct. 2527 (2011) (holding that the Clean Air Act, 42 U.S.C. $\$ 7401$ et seq. and the EPA action authorized by the Act displace any federal common-law right to seek abatement of carbon-dioxide emissions from fossil-fuel fired power plants).

219. City of Chicago v. Beretta U.S.A. Corp., 821 N.E.2d 1099, 1115 (Ill. 2004).

220. See generally Gostin, supra note 67. 
health law has relied on the overarching value of health as the justification for placing community needs on equal footing with individual rights. But this vision is in tension with the liberal foundations of American law, which require rigorous justification of community needs before they are allowed to trump individual rights. What is required is a middle position between critics, who support only the narrowest articulation of public health law as the law of communicable disease control, and defenders of new public health, who appear to understand any widespread health problem as legitimately falling within the purview of public health law.

Designating a concern as a public health threat has important legal consequences. To the extent that the public is invoked as a liberty-limiting principle, ${ }^{221}$ it should be thoughtfully defined and theorized. The problem, of course, is defining what special quality marks an interest as sufficiently collective or communal, beyond the large number of people affected. The justification provided by the public-goods and public-places theories of the public are dissatisfying in their narrowness. I propose that part of the solution to more fully theorizing the public as a justification for public health intervention is supplementation of the public goods formulation with an enhanced conception of public bads. This enhanced conception moves beyond a purely economic understanding by drawing on the science of epidemiology. I argue that epidemiological harms - those for which causation can be established at the population level, but which cannot necessarily be traced to any individual victim--should be understood as public bads. This conception offers an expanded understanding of the public as a

221. This is a hugely important caveat. An important response to the liberal critique of "new" public health law is that many of the legal tools that it promotes are not coercive. Hall's description of why environmental and occupational health regulations are not troubling-that they "affect primarily only property or economic interests, not personal liberty"-also applies to many "new" public health legal interventions to address threats like obesity. Hall, supra note 65 , at S207. A longer discussion of the extent to which particular "new" public health law tools are coercive enough to even require a robust liberty-limiting principle is outside of the scope of this Article. See Gostin \& Bloche, supra note 72, at S172 ("The 'new' public health is less coercive, in the conventional sense, than its 19 th-century regulatory antecedents. It eschews physical compulsion, such as quarantine and coerced therapy, except as a lastditch step, and it sees synergies between health promotion and respect for human rights."). In this Article, however, I am concerned with those instances in which the "public" is invoked to justify significant state intrusion. 
justification for public health intervention. It also promotes an even firmer rooting of public health law and policy in the science and practice of new public health, rather than seeking (as Hall and Epstein do) to divide the politics of public health from its science.

\section{A. A Broader Conception of the Public}

In a subtle but fundamental way, the division between science and law championed by Hall and Epstein would disconnect public health from the explicitly progressive mission that has been integral to its disciplinary identity for centuries. The dichotomy relied upon by Hall and Epstein misses important distinctions within the discipline of public health. "Eliminating threats to public health" 222 involves multiple activities. This project is far from solely "the domain"223 of law. There are at least four broad categories of activity at issue here: science, practice, policy, and law. The lines are necessarily blurred among them. It is not possible for the science of public health (the activity of "[a]dvancing understanding and knowledge of the causes and patterns of health conditions in society") 224 to exist in a vacuum. The questions it seeks to answer (and the answers it eventually provides) are informed by practice, policy, and law. The scientific identification of causal pathways is intimately tied to the policy work of developing and evaluating potential interventions to disrupt them. The practice of public health (by which I mean the activity of implementing interventions to protect and promote health, only some of which make use of legal tools) is useless unless it is informed by science and guided by policy. And public health policy (by which I mean the body of defined objectives of public health science and practice) easily blends into the law, in which it is expressed. As Daniel Goldberg has written in response to the critique of new public health put forth by Mark Rothstein, "either the social epidemiologists' contention that socioeconomic disparities are a primary factor in causing good public health is accurate, or it is not." 225

222. Hall, supra note 65 , at $\mathbf{S 2 0 2 .}$

223. Id.

224. Id.

225. Daniel S. Goldberg, In Support of a Broad Model of Public Health: Disparities, Social Epidemiology and Public Health Causation, 2 PUB. HEALTH 
[]f socioeconomic disparities are truly productive of public health, policies consistent with the narrow model, which by definition do nothing to ameliorate social conditions, will do little to actually improve health in the aggregate.... If public health practice is not intended to facilitate the public's health, it is unclear what use such practice has and why public monies should be forthcoming to support it. ${ }^{226}$

To the extent that the liberal critics of new public health seek to apply a narrow definition to all efforts to "eliminat[e] threats to public health,"227 their critique would disconnect not only public health law, but also public health policy and practice, from the progressive mission of improving population health.

The formulation of public health and public rights as limited to securing public goods ignores the wider diversity of harms that public health law and public nuisance law have been used to address, not just in the past decade, but for centuries. Earlier courts addressing public nuisances in the form of vicious dogs, 228 fireworks, ${ }^{229}$ and snake handling ${ }^{230}$ were far more comfortable with broad statements of the state's authority to enjoin and seek redress for unreasonable interferences with public health and welfare. In State ex rel. Swann v. Pack, ${ }^{231}$ for example, the Tennessee Supreme Court defined a public nuisance as "a condition of things which is prejudicial to the health, comfort, safety, property, sense of decency, or morals of the citizens at large, resulting either from an act not warranted by law, or from neglect of a duty imposed by law."232 In

ETHICs 70, 73 (2009).

226. Id. at 75 .

227. Hall, supra note 65 , at S202.

228. See Village of Northbrook v. Cannon, 377 N.E.2d 1208, 1210-13 (Ill. App. Ct. 1978) (upholding conviction for permitting dogs to run uncontrolled thereby causing a nuisance in violation of village's animal control ordinance).

229. See PPC Enterprises, Inc. v. Texas City, 76 F. Supp. 2d 750, 760 (S.D. Tex. 1999) (upholding city ordinance prohibiting the sale, possession, or use of fireworks within 5,000 feet of the city given the existence of a Texas statute authorizing a "municipality [to] define and prohibit any nuisance within the limits of the municipality and within 5,000 feet outside its limits"' (quoting TEX. Loc. Gov'T CODE ANN. § 217.042(a))).

230. See State ex rel. Swann v. Pack, 527 S.W.2d 99, 113 (Tenn. 1975) (enjoining a pastor from handling snakes as part of a religious service on the grounds that it is a common-law nuisance).

231. Id.

232. Id. 
holding that the defendants' practice of snake handling amounted to a public nuisance, the court apparently felt no need to assert a narrow public right to a community free of unrestrained venomous snakes. ${ }^{233}$ Rather, it emphasized the impact of this practice on the safety of the community as a whole in broad terms. ${ }^{234}$ When some state legislatures codified public nuisance law around the turn of the century, they too framed their definitions of nuisance in ways that relied heavily on a broad conception of collective interests in public health and welfare. ${ }^{235}$ The state's police power-its authority and responsibility for securing the public's health and welfare-has always been greater in scope than the liberal critique suggests.

The great appeal of public nuisance for advocates eager to take on problems like the illegal gun market, the contamination of urban housing stock with lead paint, and climate change is that (in theory at least) it allows plaintiffs to establish causation at the population, rather than individual, level. The doctrinal framework that should make this possible is liberty-limiting in its own way. ${ }^{236}$ By allowing for recovery of damages and or injunctive relief against private actors in the absence of proof that traces the actions of any individual defendant to the harms suffered by any individual person, public nuisance arguably threatens to infringe on economic liberty. But for decades, centuries even, this intrusion has been deemed acceptable based on the notion of the state's role (through the courts as well as through governmental plaintiffs representing the executive branch) in protecting the uniquely collective interest in healthy living conditions. In many cases, this collective interest has been framed in terms of the natural environment-as in cases involving air or water pollution. But in others it has been understood in terms of the built environment-as in cases involving obstruction of roadways or watercourses, for example. And even the social environment has been implicated in cases involving gang violence, snake handling, or brothels. The collectively held public rights recognized in the common law of public nuisance allow for

233. Id.

234. Id.

235. See, e.g., CAL. Crv. CoDE $\S 3479$ (West 2011) (originally enacted in 1872).

236. See generally Coleman \& Ripstein, supra note 165 , at 98-112 (discussing the competing liberty and security interests implicated in liability rules). 
vindication of harms that are suffered by the public as a whole, harms that cannot easily be broken down into an aggregation of private harms. In a public nuisance cause of action the plaintiff may be able to establish that the defendant's actions have contributed to unhealthy living conditions, which have resulted in harms that are quantifiable at the population level by epidemiologists, even if the plaintiff cannot establish that any particular individual is identifiable as the victim of those harms. It is out of this vision of public nuisance that I draw my proposal of epidemiological harms as a supplement to the economic conception of public bads.

\section{B. The Economic Conception of Public Bads}

Traditionally, public bads have been understood in economic terms. In nuisance law, for example, the distinction between a private nuisance and a public one can be understood in terms of the distinction between private bads and public bads. ${ }^{237}$ Private bads are "external costs that affect, and are confined to, easily defined economic agents." 238 The classic private nuisance example is that of a factory that is spewing soot and ashes on clothes strung up to dry at the neighboring laundry. The doctrine of public nuisance gives a private right of action to the owner of the laundry, which allows him or her to negotiate with the owner of the factory. But the same approach doesn't work for public bads. The nature of a public bad "is such that there is no low-cost way to insulate and partition the affected individuals in the group from the negative effect. What one group member receives, all receive." ${ }^{339}$ For example, if an entire village is affected by emissions from a local copper smelter, there is a free rider problem posed by the potential use of a private cause of action by any individual homeowner. Because any solution (in the form of abating the pollution) would benefit everyone equally, whether they had helped bear the costs of litigation or not, it is difficult for any individual homeowner to bring suit. "The cost of organizing and the tendency for individuals to free ride works against the individual's success." 240

237. Boudreaux \& Yandle, supra note 116, at 52-66.

238. Id. at 58 .

239. Id. at 59-60.

240. Id. at 61 . 
This concept of public bads as indivisible negative externalities is intimately linked to the economic concept of public goods that has played a prominent role in public health law and public nuisance law. It is perhaps more natural to describe the copper smelter problem in negative terms that focus on the public nature of the harm suffered by the homeowners of the village, rather than in affirmative terms that focus on a right to the public good of clean air, but the concept is essentially the same. Both ways of thinking about the problem emphasize economic concerns about collective action. Public health can also be conceptualized in these terms. Advocates of the new public health have identified the central importance of economic concepts like public goods and negative externalities in defining the scope of public health law at the beginning of its modern revival. "Public health ... has as its chief duty the unenviable tasks of providing common goods and controlling negative externalities, both difficult at best." 241 The herd immunity achieved through compulsory vaccination programs is readily understood as a public good that requires individual sacrifices for the common benefit. By contrast, it is more difficult to frame "lifestyle" diseases-which we have been conditioned to think of in terms of individual behavior choices - in terms of public goods. In response to Hall's and Epstein's critiques, Lawrence Gostin and Gregg Bloche have emphasized the continued role of externality analysis in justifying governmental responses to environmental toxins, insufficient time and space for exercise, and nutritionally adequate food in public schools." 242 They have also pointed to insufficient information about health risks, and the ability of private industry to influence people's preferences through marketing efforts. This statement provides a helpful starting point, but it fails to fully elaborate a substantive response to the liberal critique. For the most part, the Gostin/Bloche response focuses on revealing the classical liberal politics that underlies the emerging critique. But that only takes us so far.

241. Gostin et al., supra note 23 , at 68.

242. Gostin \& Bloche, supra note 72 , at $\mathrm{S} 165$. 


\section{An Epidemiological Conception of Public Bads}

The population focus of epidemiology provides a unique lens for analyzing legal problems, similar to that provided by economics. ${ }^{243} \mathrm{I}$ propose that "epidemiological harms"-which I define as those for which causation can be established at the population level, but which are not necessarily traceable to any particular individual as either cause or victim ${ }^{244}$-should be understood as a type of public bad. A fundamental tension in the application of tort law as a tool for protecting the public's health is that "the most potent determinants of a disease or injury are often those that are distal and incidental, observable only by comparing the incidence of a disease or injury in one population to that in another population which is not exposed to that variable." ${ }^{245}$ As my examination of industry-wide public nuisance litigation indicates, tort law has struggled to find an appropriate framework for adjudicating claims arising out of these kinds of harms. For a variety of reasons, it is also difficult to motivate sufficient political will to address these harms, even when there is substantial scientific evidence documenting their burden on society. ${ }^{246}$

My vision of epidemiological harms as public bads builds on the social epidemiological evidence that problematizes the voluntariness of supposedly "personal" health behavior choices. The classical understanding of public bads defines them primarily as indivisible harms inflicted on the public without consent. ${ }^{247}$ Epidemiological

243. See generally PARMET, supra note 22 .

244. Cf. id. at 228-38 (describing the difficulties of using tort law to address harms that can be proven at the population level); Samuel Issacharoff, Private Claims, Aggregate Rights, 2008 SUP. CT. REV. 183, 185, 215-20 (discussing the harms caused by Vioxx, which were subject only to epidemiological proof, as among a category of "underlying substantive claims which, either formally or as a practical matter, do not fit within the framework of identifiably individual claims").

245. See PARMET, supra note 22, at 228.

246. See Neiman, supra note 69 , at $226-31,240-43$ (discussing the strong resistance to mandatory motorcycle helmet laws by motorcycle enthusiasts despite overwhelming evidence that helmets significantly decrease the morbidity and mortality rates associated with motorcycle accidents); Hodge \& Eber, supra note 69 , at 520-21 (discussing strategies and obstacles to enacting and implementing tobacco-control legislation).

247. See Epstein, In Defense of the Old Public Health, supra note 83, at 1426 ("In contrast to public goods, public bads are inflicted upon others without their 
harms can be partly conceptualized in similar terms, but in a way that is informed by social epidemiology. Ultimately, it comes down to how the harm is framed. If the public bad at issue in the obesity epidemic is the ingestion of large quantities of high-calorie, lownutrient food, then it is difficult to conceive of that interaction between the individual consumer and the food he or she eats in terms of an "indivisible" harm imposed without consent. On the other hand, if the public bad at issue here is an information and food environment that has been shown to increase obesity at the population level, the calculus looks different. There is no meaningful consent to the overrepresentation of fast food outlets and underrepresentation of full service grocery stores in low-income neighborhoods. There is no meaningful consent to exposure to advertising on the sides of city busses extolling the virtues of dollarmenu cheeseburgers. Social epidemiology also suggests that these harms are indivisible, in much the same way that the pollution emitted from a copper smelting mill affects an entire community. Scientific study can establish links between the social environment and health outcomes at the population level, but not at the individual level.

Protecting public health also requires actions that no individual is fully incentivized to take, even if it were within one's power to do so, because it is impossible to know which individuals will benefit. Indeed, the collective action problem in public health is the very root of its frequent politicization. Geoffrey Rose, a prominent epidemiologist, characterized the central dilemma of public health as the "prevention paradox." 248 Interventions that have the greatest potential to improve health at the population level are virtually always impossible to link to individual benefits. We know that convincing people not to use tobacco saves lives. We can document how many fewer people are smoking today than were smoking in

consent, as are communicable diseases and pollution, but not obesity or genetic diseases."); Elizabeth Weeks Leonard, The Public's Right to Health: When Patient Rights Threaten the Commons, 86 WASH. U. L. REV. 1335, 1391-92 (2009) ("Smoking bans are consistent with traditional public health interventions ... because smoking in public is a 'public bad.' Its effects are imposed broadly on others, without their consent.").

248. Rose, supra note 18, at 42 ("[T] also some weighty drawbacks. It offers only a small benefit to each individual since most of them were going to be all right [sic] anyway, at least for many years. This leads to the prevention paradox."). 
the $1960 \mathrm{~s}^{249}$ We can even document the impact of cigarette taxes on smoking prevention. ${ }^{250}$ But it is impossible to point to any individual and say "this person's life was saved because the cigarette tax was high enough to keep her from taking up smoking." Similarly, we know that exposure to deteriorating lead paint causes intellectual impairment. We can document how many children have blood lead levels that are unsafe. At the population level, we may even be able to estimate how much intellectual disability is attributable to lead paint exposure. But it is exceedingly difficult to prove that any given individual would not be intellectually disabled but for her exposure to lead paint.

By framing the issue in terms of the nonconsensual and indivisible nature of the social, economic, and environmental determinants of health, the epidemiological harms concept offers an approach to incorporating a communitarian vision of public health within a predominantly liberal legal framework. The liberal framework tends to discount social, economic, and environmental influences on individual choice in its efforts to emphasize the importance of individual autonomy. This position is no longer fully tenable in the public health context, in light of the findings of social epidemiologists. Epstein's and Hall's arguments for a division between the science and the law of public health do not present a viable solution to this conundrum. Rather, the solution is to root new public health law more deeply in the science of social epidemiology. Legal advocates must find more compelling ways to convey the power of scientific insights about the social, economic, and environmental determinants of health. These insights ultimately provide the strongest source of support for understanding an expanding range of health threats as legitimately public in nature and as amenable to structural solutions.

249. Betsy McKay, Downward Trend in Smoking Rate Stalls, WaLl ST. J., Nov. 13, 2009, at A3, available at http://online.wsj.com/article/SB 125804680667345609.html (stating that $20.6 \%$ of American adults were smokers in 2009, down from around $40 \%$ in the mid-1960s).

250. See generally Hana Ross \& Frank J. Chaloupka, The Effect of Cigarette Prices on Youth Smoking, 12 HEALTH ECON. 217 (2003), available at http://onlinelibrary.wiley.com/doi/10.1002/hec.709/pdf (examining the effect of cigarette prices on youth smoking and concluding that higher cigarette prices reduce the probability of youth cigarette smoking). 


\section{Conclusion}

The emerging liberal critique of new public health law has far reaching implications. It calls into question the full range of strategies for using law as a tool to address modern public health threats outside of communicable diseases, environmental pollution, and contaminated food. Liberal critics apply their reasoning to "fat taxes," 251 tanning bed taxes, ${ }^{252}$ litigation against food manufacturers or retailers, ${ }^{253}$ tobacco control strategies that seek to associate social stigma with smoking, ${ }^{254}$ anti-poverty policies aimed at reducing health disparities, ${ }^{255}$ seat belt laws, firearms regulation, regulation of alcohol consumption, parental abuse and neglect, consumer product safety, and regulation of the fast food industry. ${ }^{256}$ In many ways, the failed efforts of public health advocates-of "epidemiologists as litigators"- to use public nuisance law as a tool for public health offer a concrete context in which to examine how persuasive the liberal critique might be for courts, and possibly also

251. See Epstein, supra note 11, at S154 (criticizing a hypothetical "fat tax" because it would "strike all consumers of that product no matter what their individual health profiles").

252. See Pope, supra note 9, at 15, 18-19 (discussing how the federal and state governments have begun to address the harms of tanning beds through excise taxes and age restrictions).

253. See Epstein, supra note 11, at S154 (postulating that such lawsuits "could spur individuals to eat fattier foods, if they believe the law will provide them with a non-waivable warranty against the supplier of the foods in question").

254. See Hall, supra note 65, at S200 (commenting on "the tremendous success the public health community has had in creating a strong social stigma against cigarette smoking ... by forcing smokers to huddle in designated spots outside public spaces and most larger workplaces").

255. See id. at S205 ("Just because ... poverty... interfere[s] with the health of individuals and populations does not mean that eliminating these conditions is part of the mission of public health." (quoting Rothstein, Rethinking the Meaning of Public Health, supra note 85, at 144 )). But see Hall, supra note 65, at $\mathrm{S} 201$ ("To address comprehensively the problem of health inequalities, governments must begin to address the issue of our economic inequalities per se." (quoting Norman Daniels et al., Why Justice is Good for Our Health: The Social Determinants of Health Inequalities, 128 DAEDALus 215, $241(1999)))$.

256. See id. at S202 (stating that classifying "excess weight as a public health concern rather than simply as a matter of individual health behavior leads to a whole new way of thinking about... regulation of the fast food industry"). 
for policymakers. Public health advocates would be wise to cull insights from the public nuisance debate that might be helpful in the public health battles on the horizon.

If the ecological model of public health intervention is ultimately going to gain political and legal traction, then advocates will have to find more powerful ways of justifying it in the face of a longstanding classical liberal political tradition. ${ }^{257}$ They must find new ways of conveying the impact of public health threats on communities-as distinct from the sum of the impacts on individuals within them. The gun violence that David Kairys described is not merely the aggregation of the effects of guns on individual friends and family members of those who are killed or injured. It is different in kind and it is described in ecological terms: "a climate of fear that undermines our communities and the positive sense of community." 258 The communitarian foundations of public health law and the insights of social epidemiology are unlikely to lead to revolution. It is not only infeasible, but also inadvisable, to attempt somehow to surmount the liberal tradition in American law. But that liberal tradition can and should be supplemented by the communitarian language of public health. Legal analysis using a lens that draws on the objectives and methodology of public health science offers a means for doing so.

257. See, e.g., Wallack \& Lawrence, supra note 77, at 568 (discussing how the values of equality, fairness, and compassion are closely associated with the modern, broad view of public health, values which are more limited in the United States than in other Western democracies).

258. Kairys, Origin and Development, supra note 128, at 1165. 